\title{
Policy Uncertainty and Mergers and Acquisitions
}

\author{
Nam H. Nguyen and Hieu V. Phan*
}

\begin{abstract}
This research examines the relationship between policy uncertainty and mergers and acquisitions (M\&As). We find that policy uncertainty is negatively related to firm acquisitiveness and positively related to the time it takes to complete M\&A deals. In addition, policy uncertainty motivates acquirers to use stock for payment and to pay lower bid premiums. Acquirers, on average, create larger shareholder value from M\&A deals undertaken during periods of high policy uncertainty, which is attributable to their prudence as well as the wealth transfer from the financially constrained targets to acquirers.
\end{abstract}

\section{Introduction}

Policy uncertainty can harm the economy. Stock and Watson (2012), Julio and Yook (2012), and Gulen and Ion (2016) argue that uncertainty related to tax, government spending, and regulatory and monetary policies hampers the postGreat Recession economic recovery. Organizations such as the Federal Open Market Committee (FOMC) and International Monetary Fund (2012) came to a similar conclusion about the effects of policy uncertainty on the economy. ${ }^{1}$ Baker, Bloom, and Davis (2016) show that the level of U.S. policy uncertainty increased by $50 \%$ over the period 1985-2012, particularly due to the federal debt-ceiling battles and the political fights over extending the Bush tax cuts in the later years.

\footnotetext{
*Nguyen, nam_nguyen@uml.edu, School of Management, Université du Québec à Montréal; Phan (corresponding author), hieu_phan@uml.edu, Manning School of Business, University of Massachusetts Lowell. This paper was written while Nguyen was a Ph.D. student at the University of Massachusetts Lowell. We are especially grateful to Art Durnev (the referee), whose comments on the paper substantially improved the exposition and analyses. We also appreciate the helpful comments from Julian Atanassov, Brian Baugh, Sudip Datta, Kathleen Farrell, Geoffrey Friesen, Steven Freund, Jarrad Harford (the editor), Mai Iskandar-Datta, Anand Jha, Sedzro Komlan, Tunde Kovacs, Manoj Kulchania, Saira Latif, Kooli Maher, Ranjan D’Mello, Stas Nikolova, Shakil Quayes, Guay Richard, Emre Unlu, John Wagster, Jing Wang, Liying Wang, Julie Wu, and Mouchette Xavier as well as session participants at the 2016 Financial Management Association Doctoral Consortium and seminar participants at the University of Massachusetts Lowell, University of Nebraska Lincoln, Université du Québec à Montréal, and Wayne State University. We thank Di Huang for sharing the fuzzy matching codes. All errors remain the sole responsibility of the authors.

${ }^{1}$ http://www.federalreserve.gov/monetarypolicy/fomcminutes20091216.htm
} 
Business media reported that the increase in policy uncertainty led to a decrease of more than 1 percentage point in the real gross domestic product (GDP) and the loss of over 1 million jobs in the United States during the period 2011-2012. ${ }^{2}$ Given the far-reaching consequences of policy uncertainty, researchers and policymakers have been increasingly interested in investigating its effects on corporate behavior and firm value.

The relationship between uncertainty and corporate investments is unclear ex ante. Hartman (1972), Abel (1983), and Caballero (1991) argue theoretically that output price uncertainty may increase the investments of risk-neutral firms operating in perfect competition with a constant returns-to-scale production function and no irreversibility. However, other research argues that firms are likely to delay irreversible investments amid uncertainty (Bernanke (1983), McDonald and Siegel (1986), Dixit and Pindyck (1994), Abel and Eberly (1994), and Gulen and Ion (2016)). Policy uncertainty can exacerbate firms' financial constraints and increase the cost of external financing (Greenwald and Stiglitz (1990), Pástor and Veronesi (2013), Gilchrist, Sim, and Zakrajšek (2014), and Brogaard and Detzel (2015)) and increase managerial risk aversion (Panousi and Papanikolaou (2012)). However, no prior study has investigated the link between policy uncertainty and mergers and acquisitions (M\&As), one of the most important forms of corporate investments. This research attempts to fill this gap by empirically investigating the relationship between policy uncertainty and M\&As and its implications for shareholder value. ${ }^{3}$

We examine the effects of policy uncertainty on firm acquisitiveness, the time it takes to complete the M\&A deals, the payment consideration, and acquirer and target shareholder value. M\&As are typically large and difficult-to-reverse investments. They also represent managers' discretionary risk taking and tend to increase the acquirers' default risk (Furfine and Rosen (2011), Phan (2014)). Therefore, consistent with recent evidence documented in the literature, we predict a negative relationship between policy uncertainty and firm acquisitiveness. Moreover, from the real option perspective, firms are more likely to delay irreversible investments until some of the uncertainty is resolved (Bernanke (1983), Dixit and Pindyck (1994)). This observation suggests that even if the acquiring firms engaged in M\&A bids, it would take them more time to complete the deals during periods of high policy uncertainty.

We use the policy uncertainty index developed by Baker, Bloom, and Davis (BBD) (2016) as a proxy for policy-related economic uncertainty to examine its effect on M\&As. The BBD index is constructed based on the weighted average of three components: the frequency of newspaper articles containing key terms related to policy uncertainty, uncertainty about future changes in the federal tax code measured by the dollar impact of tax provisions set to expire in the near future, and the dispersion in economic forecasts of government spending and Consumer Price Index (CPI) as a proxy for uncertainty about future fiscal and monetary policy.

\footnotetext{
${ }^{2}$ Wall Street Journal, Apr. 28, 2013. Available at http://www.wsj.com/articles/SB1000142412788 7323789704578443431277889520

${ }^{3}$ It came to our attention that Alice Bonaime, Huseyin Gulen, and Mihai Ion were working independently on a similar research topic.
} 
Using a sample of 88,768 firm-year observations of 9,673 unique firms over the period 1986-2014, we find a negative relationship between policy uncertainty and firm acquisitiveness. Our estimation indicates that a 1-standard-deviation increase in the BBD (2016) index value is associated with a 5.8-percentage-point decrease in the acquisition probability of an average firm, which is economically important given the sample's unconditional M\&A probability of $23.71 \%$, and a decrease of $\$ 30.1$ million in average M\&A deal value. Moreover, our analysis of the completed M\&A deals indicates that policy uncertainty is positively related to the time it takes to complete the deals.

Policy uncertainty tends to be countercyclical, and both policy uncertainty and M\&As can be jointly correlated with unobservable factors, such as investment opportunities, which raises an endogeneity concern and renders our probit model's coefficient estimates biased and inconsistent. To address this endogeneity concern, we employ an instrumental variable (IV) probit model and use a measure of the U.S. Senate's political polarization as an instrument for policy uncertainty. The IV probit estimation results indicate that our findings are robust to endogeneity correction.

The BBD (2016) index may capture other, nonpolicy-related economic uncertainty (e.g., currency uncertainty, stock price volatility, oil price shocks, or labor market variations), which suggests a potential error-in-measurement problem that biases the M\&A probit estimation results. Gulen and Ion (2016) argue that the U.S. and Canadian economies are closely related, and therefore a shock that affects the economic uncertainty in the United States is likely to affect the economic uncertainty in Canada as well. Following their argument, we estimate the BBD index for the United States as a function of the Canadian BBD index and other macroeconomic variables, then use the regression residuals as a proxy for policy uncertainty in the M\&A probit regressions; however, our finding is qualitatively unchanged.

Policy uncertainty can exacerbate firms' financial constraints, expose them to higher default risk, and make it harder and more costly for acquiring firms to raise external funds to support M\&A deals. In addition, policy uncertainty can increase future cash flow volatility, which increases firm risk. Faced with policy uncertainty and its adverse effects, acquiring firms are expected to be prudent with their liquidity and are more (less) likely to use stock (cash) for M\&A payment. Our analysis of the acquirers' payment consideration indicates that policy uncertainty is positively related to all-stock payment as well as the percentage of stock used for M\&A payment. We further investigate and find a negative relationship between policy uncertainty and bid premiums, which suggests that policy uncertainty induces acquirers to be more conservative in setting the bid prices.

Policy uncertainty can increase firms' operating risk, amplify the risk of large investments such as M\&As, and increase the costs of capital, potentially leading to a decrease in acquirer shareholder value. However, as firms become more prudent and tend to delay large and risky investments during the high-uncertainty periods (Bernanke (1983), Rodrik (1991), Bloom, Bond, and Reenen (2007), and Gulen and Ion (2016)), acquirers are likely to engage in those M\&A deals that are expected to produce better outcomes. This proposition implies a positive relationship between policy uncertainty and acquirer shareholder value. Given the 
possible opposing effects of policy uncertainty on acquirer shareholder value, we will need to sort them out empirically.

We examine the effect of policy uncertainty on both short-term and long-term acquirer shareholder value. We run cross-sectional regressions of the acquirers' 3-day cumulative abnormal returns (CARs) centered on the deal announcement day to capture the short-term effect of policy uncertainty on acquirer shareholder value. The regression results reveal a positive relationship between policy uncertainty and acquirer CARs. Because pursuing M\&As is a firm decision rather than a random assignment, our cross-sectional regression results could be prone to the self-selection bias. Therefore, we employ the Heckman (1976), (1979) 2-step selfselection correction model to address the self-selection bias concern, but we find robust results. The economic effect of policy uncertainty on acquirer shareholder value is also important. Our point estimates indicate that, holding other variables fixed at their sample means, a 1-standard-deviation increase in the BBD (2016) index value above its sample mean is associated with an increase of 70 basis points (bps) (i.e., $0.7 \%$ ) or $\$ 31.4$ million in an average acquirer's shareholder value. Our further analysis indicates that the positive effect of policy uncertainty on acquirer CARs is attributable to the acquirers' prudence with M\&As and the value transfer from the financially constrained targets' to acquirers' shareholders.

We complement our short-term value analysis with an investigation of the effect of policy uncertainty on acquirer long-term stock and operating performance. We employ the buy-and-hold abnormal returns (BHARs) using the matched firmadjusted method suggested by Barber and Lyon (1997) and Lyon, Barber, and Tsai (1999) as a proxy for long-term stock performance. We use the long-term abnormal operating performance calculated based on the matched firm-adjusted method suggested by Barber and Lyon (1996) as a proxy for long-term operating performance. Our analysis indicates that acquirer long-term stock and operating performance is positively related to policy uncertainty, implying a positive relationship between policy uncertainty and acquisition synergies. Overall, our findings demonstrate that policy uncertainty not only reduces firm acquisitiveness or delays M\&A deal consummation but also motivates acquirers to exercise a careful screening of acquisition targets and prudence with the acquisition terms, thereby creating value for acquirer shareholders.

There is a stream of literature that examines the effects of political uncertainty on corporate behavior (e.g., Julio and Yook (2012), Jens (2017)); however, it is worth noting that political uncertainty is different from policy uncertainty in a number of ways. Political uncertainty is typically associated with specific political events, such as presidential elections (Julio and Yook) or gubernatorial elections (Jens). Gulen and Ion (2016) argue that although elections may be good exogenous indicators of uncertainty, they do not tell how policy uncertainty changes during these elections. Moreover, the election indicator variable used in empirical studies does not capture the variation in policy uncertainty between elections. On the other hand, policy uncertainty is broader and includes different types of uncertainty that are directly tied to policies. It is noteworthy that the BBD (2016) index spikes during events that are associated with high policy uncertainty, such as the Gulf Wars, the 9/11 attack, the 2011 debt-ceiling dispute, and battles over fiscal policy. We are interested in policy uncertainty because it can have a 
profound impact on important corporate decisions, such as those related to M\&As, in a continuous fashion. To ensure that our findings are not confounded by the effects of political uncertainty, we perform additional analyses that explicitly control for political uncertainty, but our results are qualitatively unchanged.

Our research contributes to the literature in three important ways. First, our study adds to a growing stream of literature that examines the effects of policy uncertainty on corporate decisions (e.g., Bloom et al. (2007), Gulen and Ion (2016), and Baker et al. (2016)). Our research focuses on the relationship between policy uncertainty and M\&As, one of the most important forms of corporate investments, and further considers its effect on acquirer shareholder value. Second, our research highlights the negative effect of policy uncertainty on financially constrained firms' operations. Our evidence suggests that policy uncertainty weakens the bargaining power of financially constrained targets, resulting in a lower value for their shareholders. Finally, our research findings can have timely implications for policy and corporate decision makers, which can be particularly useful given the recent wide swings in policy uncertainty and its adverse effects on the real economy.

Our research is close to that of Gulen and Ion (2016), who investigate the effect of policy uncertainty on capital expenditures. However, we focus on a different type of investment, M\&As, which are typically large and readily observable. We further examine the implications of policy uncertainty for shareholder value, which suggests a channel through which policy uncertainty affects corporate investments. Our research is also related to that of Bhagwat, Dam, and Harford (2016), who investigate the relationship between stock market volatility and $M \& A$ activities. However, we note that the variable of interest in our research is policy uncertainty proxied by the BBD (2016) index, whereas Bhagwat et al.'s variable of interest is stock market uncertainty proxied by the Chicago Board Options Exchange (CBOE) Volatility Index (VIX). Baker et al. (2016) point out that the BBD and VIX indices are different in measurement, time frame, and implications. In particular, the VIX index is constructed based on the implied volatility of 30-day maturity put and call options, whereas the BBD index is based on newspaper coverage, the future expiration of the federal tax code, and forecaster disagreements about future fiscal and monetary policies. Moreover, the VIX index is more related to financial and stock market events, such as the 1997 Asian crisis, the 1998 Russian crisis, and the 2002 stock market scandals, whereas the policy uncertainty index reflects more policy-relevant events. Finally, the VIX index is related to short-run financial uncertainty, whereas the BBD index tends to capture the long-run policy uncertainty.

The remainder of the paper is organized as follows: We present a description of the data and variables construction in Section II. Section III develops empirical predictions and discusses the research methods and results. Section IV presents robustness checks, and Section V concludes the paper. 


\section{Samples, Variables Construction, and Descriptive Statistics}

We form the sample for our investigation of the relationship between policy uncertainty and firm acquisitiveness using the universe of firms included in the Compustat database. Following the literature, we exclude firms from the utility (Standard Industrial Classification (SIC) codes 4900-4999) and financial industries (SIC codes 6000-6999) from the analysis because these industries are highly regulated. We obtain accounting data from Compustat and stock price and return data from the Center for Research in Security Prices (CRSP) database. The M\&A data are from the Platinum Database of the Securities Data Company (SDC). We merge Compustat data with the M\&A data to form the full sample for M\&A likelihood analysis. Following the literature, we filter out those M\&A deals with values below $\$ 1$ million and deal ratios, measured as the ratio of the deal value to the acquirer market capitalization, below $1 \%$ to form the M\&A subsample for cross-sectional analysis.

We use the BBD index developed by Baker et al. (2016) to proxy for policy uncertainty, our test variable. Baker et al. construct the monthly policy uncertainty index as the weighted average of three components: a count of the news articles that contain uncertainty-related key terms, uncertainty about future changes in the federal tax code as measured by the dollar impact of tax provisions set to expire in the near future, and dispersion in economic forecasts of government spending and CPI as a proxy for uncertainty about future fiscal and monetary policy. These authors normalize each component and assign a weight of $1 / 2$ for news-based, 1/6 for tax, and 1/3 for forecaster disagreement components. For our research purpose, we construct the policy uncertainty variable as the natural logarithm of the weighted average of the BBD index values of the last 3-month period of a fiscal year for a given firm. ${ }^{4}$

The first component of the BBD (2016) index, the news-based uncertainty, captures the intensity of concerns about policy uncertainty. The news-based uncertainty is obtained from 10 large newspapers: USA Today, the Miami Herald, the Chicago Tribune, the Washington Post, the Los Angeles Times, the Boston Globe, the San Francisco Chronicle, the Dallas Morning News, the New York Times, and the Wall Street Journal. An article will be counted if it contains terms in all three categories related to uncertainty, the economy, and policy, as follows: "uncertainty" or "uncertain"; "economic" or "economy"; and "Congress," "legislation," "White House," "regulation," "Federal Reserve," or "deficit." Baker et al. (2016) find that the news-based uncertainty increases with intense news coverage of events such as a stock market crash (Black Monday), the Gulf Wars, a terrorist attack (9/11), the Lehman Brothers bankruptcy, or the 2011 debt-ceiling dispute.

Baker et al. (2016) estimate the level of uncertainty related to future changes to the tax code by the discounted value of the revenue effects of all tax provisions set to expire over the next 10 years. The federal tax code provision expiration data

\footnotetext{
${ }^{4}$ Specifically, the weighted-average policy uncertainty value $\mathrm{PU}_{t}=\left(\right.$ INDEX_VALUE $_{t-3}+2 \times$ INDEX_VALUE $_{t-2}+3 \times$ INDEX_VALUE $\left._{t-1}\right) / 6$. Our findings are qualitatively similar if we use the arithmetic mean or weighted average of the last 3-, 6-, or 12-month BBD (2016) index values.
} 
are acquired from the Congressional Budget Office. Finally, these authors estimate the inflation and government purchase dispersion by computing the average of the interquartile ranges of CPI and federal, state, and local government spending forecasts. The fiscal and monetary policies data are obtained from the Federal Reserve Bank of Philadelphia's Survey of Professional Forecasters.

We report the annual and 2-digit SIC code industry M\&A deal distributions of the M\&A subsample in Panels A and B, respectively, of Table 1. The annual number of M\&A deals increased gradually over the period 1986-2006 but

TABLE 1

Distribution of M\&As by Year and Industry

Table 1 reports the annual and 2-digit SIC code industry distribution of the mergers and acquisitions (M\&A) subsample for the sample period 1986-2014.

Panel A. M\&A Subsample Distribution by Year

\begin{tabular}{|c|c|c|c|}
\hline Year & Frequency & & Percentage \\
\hline 1986 & 10 & & 0.16 \\
\hline 1987 & 11 & & 0.17 \\
\hline 1988 & 9 & & 0.14 \\
\hline 1989 & 8 & & 0.13 \\
\hline 1990 & 14 & & 0.22 \\
\hline 1991 & 21 & & 0.33 \\
\hline 1992 & 23 & & 0.36 \\
\hline 1993 & 29 & & 0.45 \\
\hline 1994 & 44 & & 0.69 \\
\hline 1995 & 194 & & 3.04 \\
\hline 1996 & 198 & & 3.11 \\
\hline 1997 & 260 & & 4.08 \\
\hline 1998 & 273 & & 4.28 \\
\hline 1999 & 282 & & 4.42 \\
\hline 2000 & 261 & & 4.09 \\
\hline 2001 & 231 & & 3.62 \\
\hline 2002 & 263 & & 4.12 \\
\hline 2003 & 304 & & 4.77 \\
\hline 2004 & 424 & & 6.65 \\
\hline 2005 & 363 & & 5.69 \\
\hline 2006 & 427 & & 6.70 \\
\hline 2007 & 328 & & 5.14 \\
\hline 2008 & 244 & & 3.83 \\
\hline 2009 & 215 & & 3.37 \\
\hline 2010 & 414 & & 6.49 \\
\hline 2011 & 539 & & 8.45 \\
\hline 2012 & 448 & & 7.03 \\
\hline 2013 & 308 & & 4.83 \\
\hline 2014 & 231 & & 3.62 \\
\hline Total & 6,376 & & 100 \\
\hline \multicolumn{4}{|c|}{ Panel B. M\&A Distribution by Industries } \\
\hline 2-Digit SIC & Industry Description & Frequency & Percentage \\
\hline 73 & Business services & 952 & 14.93 \\
\hline 36 & Electronic and other electrical equipment & 640 & 10.04 \\
\hline 38 & Instruments and related products & 570 & 8.94 \\
\hline 28 & Chemicals and allied products & 544 & 8.53 \\
\hline 35 & Industrial and commercial machinery and computer equipment & 471 & 7.39 \\
\hline 13 & Oil and gas extraction & 404 & 6.34 \\
\hline 48 & Communications & 232 & 3.64 \\
\hline 80 & Health services & 166 & 2.60 \\
\hline 37 & Transportation equipment & 165 & 2.59 \\
\hline 50 & Wholesale trade-durable goods & 153 & 2.40 \\
\hline 87 & Engineering and management services & 144 & 2.26 \\
\hline 59 & Miscellaneous retail & 133 & 2.09 \\
\hline \multirow[t]{2}{*}{20} & Food and kindred products & 131 & 2.05 \\
\hline & Industries with $<2 \%$ representation & 1,671 & 26.21 \\
\hline Total & & 6,376 & 100.00 \\
\hline
\end{tabular}


dropped significantly during the period 2007-2009 due to the Great Recession before increasing again in 2010. M\&A deals were concentrated in some industries, including business services, electronic and electrical equipment, instruments and related products, oil and gas extraction, industrial, transportation equipment, health services, food and kindred products, wholesale trade-durable goods, and engineering and management services.

Table 2 presents the descriptive statistics of the full sample and the M\&A subsample in Panels A and B, respectively. The full sample consists of 88,768 firm-year observations of 9,673 unique firms, and the M\&A subsample has 6,376 firm-year observations of 2,950 unique firms. MARKET-TO-BOOKRATIO is the market value of assets, which is calculated as the market value of equity plus the book value of assets minus the book value of equity, divided by the book value of assets. BOOK_LEVERAGE is the ratio of the book value of debt to the book value of assets. PAST_12_MONTH_RETURN is the prior 12-month cumulative returns. AVERAGE_SALES_GROWTH is the average of the annual sales growth over the last 3 years. FIRM_AGE is the number of years a firm appears in the Compustat database. Other variables are defined in the Appendix. The average BBD (2016) index values of the full sample (108.82) and the M\&A subsample (113.08) are slightly larger than the value (100) reported by Baker et al. (2016). The means of the previous 12-month cumulative stock returns, sales growth rate, market-to-book ratio, firm size, and firm age of the M\&A subsample are higher than those of the full sample.

TABLE 2

Summary Statistics

Table 2 reports the descriptive statistics of the full sample and the M\&A subsample in Panels $A$ and $B$, respectively. POLICY_UNCERTAINTY is the weighted average of the Baker, Bloom, and Davis (BBD) (2016) index over the 3-month period at the end of a given year. SIZE is the natural logarithm of the book value of assets. MARKET-TO-BOOK_RATIO is the ratio of the market value of assets to the book value of assets. BOOK_LEVERAGE is the ratio of the book value of debt to the book value of assets. PAST_12_MONTH_RETURNS is the acquirer 12-month buy-and-hold stock return in the preceding year. AVERAGE_SALES_GROWTH is the average annual sales growth rate over a 3-year period. NONCASH_ WORKING_CAPITAL is the ratio of working capital minus cash, divided by the book value of assets. FIRM_AGE is the number of years a firm appears in the Compustat database. Other variables are defined in the Appendix.

\begin{tabular}{|c|c|c|c|c|c|c|}
\hline Variable & $N$ & Mean & Q1 & Median & Q3 & $\underline{\text { Std. Dev. }}$ \\
\hline \multicolumn{7}{|l|}{ Panel A. Full Sample } \\
\hline $\begin{array}{l}\text { POLICY_UNCERTAINTY } \\
\text { SIZE } \\
\text { MARKET-TO-BOOK_RATIO } \\
\text { PAST_12_MONTH_RETURNS } \\
\text { AVERAGE_SALES_GROWTH } \\
\text { BOOK_LEVERAGE } \\
\text { NONCASH_WORKING_CAPITAL } \\
\text { FIRM_AGE }\end{array}$ & $\begin{array}{l}88,768 \\
88,768 \\
88,768 \\
88,768 \\
88,768 \\
88,768 \\
88,768 \\
88,768\end{array}$ & $\begin{array}{c}108.82 \\
5.532 \\
1.546 \\
0.163 \\
0.193 \\
0.216 \\
0.314 \\
19.51\end{array}$ & $\begin{array}{r}86.368 \\
3.873 \\
0.768 \\
-0.224 \\
0.014 \\
0.035 \\
0.155 \\
9.00\end{array}$ & $\begin{array}{r}101.83 \\
5.423 \\
1.105 \\
0.061 \\
0.097 \\
0.187 \\
0.297 \\
15.00\end{array}$ & $\begin{array}{r}126.73 \\
7.061 \\
1.769 \\
0.379 \\
0.222 \\
0.336 \\
0.450 \\
27.00\end{array}$ & $\begin{array}{c}31.363 \\
2.213 \\
1.356 \\
0.649 \\
0.437 \\
0.197 \\
0.193 \\
13.02\end{array}$ \\
\hline \multicolumn{7}{|l|}{ Panel B. M\&A Subsample } \\
\hline $\begin{array}{l}\text { POLICY_UNCERTAINTY } \\
\text { SIZE } \\
\text { MARKET-TO-BOOK_RATIO } \\
\text { PAST_12_MONTH_RETURNS } \\
\text { AVERAGE_SALES_GROWTH } \\
\text { BOOK_LEVERAGE } \\
\text { NONCASH_WORKING_CAPITAL } \\
\text { FIRM_AGE }\end{array}$ & $\begin{array}{l}6,376 \\
6,376 \\
6,376 \\
6,376 \\
6,376 \\
6,376 \\
6,376 \\
6,376\end{array}$ & $\begin{array}{c}113.08 \\
6.324 \\
1.718 \\
0.262 \\
0.202 \\
0.203 \\
0.280 \\
20.90\end{array}$ & $\begin{array}{r}78.585 \\
5.015 \\
0.933 \\
-0.109 \\
0.025 \\
0.016 \\
0.140 \\
10.00\end{array}$ & $\begin{array}{r}99.521 \\
6.290 \\
1.331 \\
0.152 \\
0.112 \\
0.171 \\
0.260 \\
16.00\end{array}$ & $\begin{array}{r}144.16 \\
7.586 \\
1.993 \\
0.464 \\
0.247 \\
0.318 \\
0.390 \\
28.00\end{array}$ & $\begin{array}{c}38.044 \\
1.909 \\
1.315 \\
0.641 \\
0.395 \\
0.195 \\
0.174 \\
14.29\end{array}$ \\
\hline
\end{tabular}


Figure 1 plots the BBD (2016) index with M\&A deal number and value over the sample period. The figure indicates that both $M \& A$ deal number and value spiked when policy uncertainty was low.

\section{FIGURE 1}

Policy Uncertainty and Aggregate M\&A Deal Volume and Value

Figure 1 plots annual M\&A deal volume (Graph A) and aggregate M\&A deal value (Graph B) with BBD (2016) policy uncertainty index over the sample period 1986-2014.
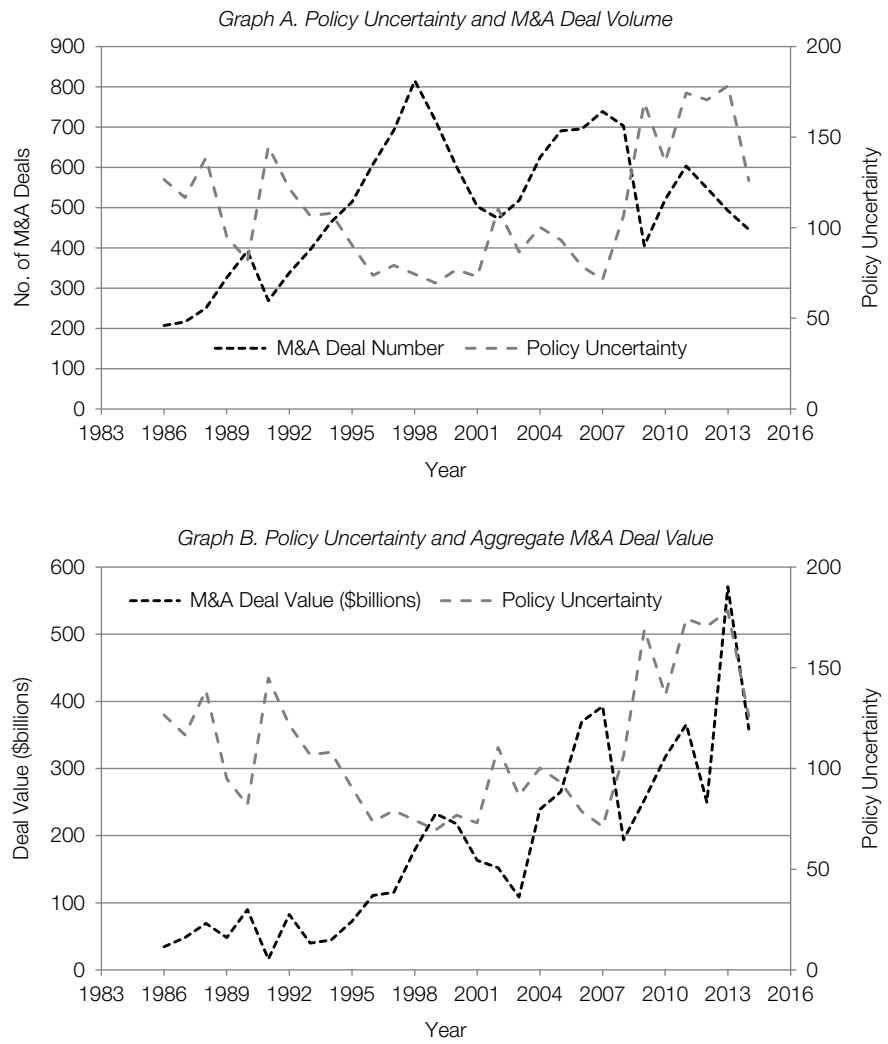

\section{Empirical Predictions, Research Methods, Results, and Discussions}

\section{A. Policy Uncertainty, M\&A Likelihood, and Time to Deal Completion}

The sign of the effect of policy uncertainty on corporate investments is unclear ex ante. Hartman (1972), Abel (1983), and Caballero (1991) argue theoretically that under strict assumptions of risk-neutral firms operating in perfect competition with a constant returns-to-scale production function and no irreversibility, output price uncertainty may increase investment. However, a growing stream of research suggests that uncertainty has a negative effect on corporate investments. Bernanke (1983), Rodrik (1991), and Dixit and Pindyck 
(1994) argue that if investment projects are irreversible, firms are more likely to delay them during periods of high uncertainty. Gulen and Ion (2016) show empirically that policy uncertainty has a negative effect on corporate investments. Policy uncertainty can also increase a firm's default risk and costs of capital (Pástor and Veronesi (2013), Gilchrist et al. (2014), and Brogaard and Detzel (2015)) and induce managerial risk-averse behavior (Panousi and Papanikolaou (2012)). M\&As are one of the largest and most important corporate investments. In addition, M\&As, on average, increase acquirer risk (Furfine and Rosen (2011), Phan (2014)). Given the large capital commitment to and the irreversibility of M\&A deals, we predict a negative relationship between policy uncertainty and a firm's acquisitiveness. Moreover, even if firms decided to pursue M\&As in the first place, we expect that policy uncertainty would lengthen the time it takes acquirers to complete the deals.

We use the following probit model to investigate the relationship between policy uncertainty and firm acquisitiveness:

$$
\begin{aligned}
\text { M\&A_DUMMY }_{i, t}= & \alpha+\beta \times \mathrm{PU}_{t-1}+\mathbf{C}_{i, t-1} \times \lambda \\
& +\gamma \text { INDUSTRY_FIXED_EFFECTS }+\varepsilon_{i, t},
\end{aligned}
$$

where M\&A_DUMMY is an indicator that equals 1 if firm $i$ makes at least one acquisition announcement in year $t$, and 0 otherwise. PU is the policy uncertainty variable, which is measured as the natural logarithm of the weighted average of the BBD (2016) index over the last 3-month period of the preceding fiscal year. $\mathbf{C}$ is a vector of control variables. We follow the M\&A literature in controlling for firm characteristics that have power in explaining firm acquisitiveness, including SIZE, MARKET-TO-BOOK_RATIO, BOOK_LEVERAGE, PAST 12_MONTH_RETURNS, FIRM_AGE, NONCASH_WORKING_CAPITAL, and AVERAGE_SALES_GROWTH over the last 3 years. We further control for common industry factors that could affect acquisitiveness by including industry fixed effects in the regressions. ${ }^{5}$ Because all firms are subject to the same policy uncertainty at a given point in time, we cluster the standard errors in this and other following regressions by years. ${ }^{6}$ The definitions of the variables are provided in the Appendix.

Table 3 reports the estimation results of the M\&A probit regressions. In column 1 , the coefficient of PU is negative $(-0.209)$ and statistically significant at the $5 \%$ level, indicating that firm acquisitiveness is negatively related to policy uncertainty. Using the coefficient estimates to calculate the economic effect of policy uncertainty, we find that, holding other variables unchanged at their sample means, a 1-standard-deviation increase in PU above its mean is associated with a 5.8-percentage-point decrease in acquisition probability, which is economically important given the sample's unconditional M\&A probability of $23.71 \%$.

Policy uncertainty is expected to have stronger effects on those firms that are more prone to the components of policy uncertainty (e.g., government

\footnotetext{
${ }^{5}$ Because firms are subject to the same policy uncertainty in a given year, we do not include year fixed effects in the regressions because they will capture most of the explanatory power of policy uncertainty. However, we control for time-varying macroeconomic conditions by including variables that proxy for macroeconomic forces in the robustness-check section.

${ }^{6}$ Clustering the standard errors by firms yields qualitatively similar results.
} 
TABLE 3

Policy Uncertainty and Firm Acquisitiveness

Table 3 reports the M\&A probit regression results. The dependent variable is M\&A DUMMY, which takes a value of 1 if a firm makes at least one M\&A announcement in a given year, and 0 otherwise. PU is the natural logarithm of the weighted average of the Baker, Bloom, and Davis (BBD) (2016) policy uncertainty index over the 3-month period at the end of the preceding fiscal year. Other variables are defined in the Appendix. Industries dependent on government spending include defense, health care, engineering services, and heavy construction. $Z$-statistics based on heteroscedasticityrobust standard errors clustered by years are reported in parentheses. ${ }^{*},{ }^{* *}$, and ${ }^{* *}$ indicate significance at the $10 \%$, $5 \%$, and $1 \%$ levels, respectively.

\begin{tabular}{|c|c|c|c|c|c|}
\hline & \multicolumn{5}{|c|}{ Dependent Variable: M\&A_DUMMY } \\
\hline & & $\begin{array}{c}\text { Sales to } \\
\text { Government } \\
>\$ 1 \text { Million }\end{array}$ & $\begin{array}{l}\text { Sales to } \\
\text { Government } \\
\leq \$ 1 \text { Million }\end{array}$ & $\begin{array}{l}\text { Industries } \\
\text { Dependent on } \\
\text { Government } \\
\text { Spending }\end{array}$ & $\begin{array}{l}\text { Remaining } \\
\text { Industries }\end{array}$ \\
\hline Variable & 1 & 2 & 3 & 4 & 5 \\
\hline $\mathrm{PU}$ & $\begin{array}{c}-0.209^{\star \star} \\
(2.39)\end{array}$ & $\begin{array}{l}-0.171^{\star \star \star} \\
(3.96)\end{array}$ & $\begin{array}{r}-0.007 \\
(0.05)\end{array}$ & $\begin{array}{c}-0.394^{\star \star} \\
(2.47)\end{array}$ & $\begin{array}{c}-0.045^{\star *} \\
(2.11)\end{array}$ \\
\hline SIZE & $\begin{array}{l}0.169^{\text {*** }} \\
(18.06)\end{array}$ & $\begin{array}{l}0.209^{* * *} \\
(26.86)\end{array}$ & $\begin{array}{l}0.153^{\star \star \star} \\
(12.87)\end{array}$ & $\begin{array}{l}0.182^{\star \star \star} \\
(7.57)\end{array}$ & $\begin{array}{l}0.160^{* * *} \\
(63.32)\end{array}$ \\
\hline MARKET-TO-BOOK_RATIO & $\begin{array}{l}0.042^{\star \star \star} \\
(5.38)\end{array}$ & $\begin{array}{l}0.036^{\star \star \star} \\
(3.21)\end{array}$ & $\begin{array}{l}0.049^{\star \star \star} \\
(4.64)\end{array}$ & $\begin{array}{c}0.033 \\
(1.25)\end{array}$ & 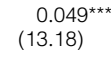 \\
\hline PAST_12_MONTH_RETURNS & $\begin{array}{l}0.102^{* * *} \\
(4.13)\end{array}$ & $\begin{array}{l}0.112^{\star * *} \\
(4.85)\end{array}$ & $\begin{array}{l}0.100^{\star \star \star} \\
(3.10)\end{array}$ & $\begin{array}{l}0.187^{\star \star \star} \\
(5.32)\end{array}$ & $\begin{array}{l}0.098^{\text {***}} \\
(12.95)\end{array}$ \\
\hline AVERAGE_SALES_GROWTH & $\begin{array}{l}0.050^{* * *} \\
(3.44)\end{array}$ & $\begin{array}{l}0.141^{* * *} \\
(3.33)\end{array}$ & $\begin{array}{r}0.031 \\
(1.40)\end{array}$ & $\begin{array}{c}-0.028 \\
(0.48)\end{array}$ & $\begin{array}{l}0.034^{\text {***}} \\
(2.92)\end{array}$ \\
\hline BOOK_LEVERAGE & $\begin{array}{l}-0.416^{\star \star \star} \\
(11.45)\end{array}$ & $\begin{array}{l}-0.663^{\star \star \star} \\
(7.55)\end{array}$ & $\begin{array}{c}-0.402^{\star \star \star} \\
(7.41)\end{array}$ & $\begin{array}{c}-0.232 \\
(1.28)\end{array}$ & $\begin{array}{l}-0.511^{\star \star \star} \\
(18.67)\end{array}$ \\
\hline NONCASH_WORKING_CAPITAL & $\begin{array}{l}0.244^{\star * *} \\
(4.38)\end{array}$ & $\begin{array}{l}0.243^{\text {** }} \\
(2.55)\end{array}$ & $\begin{array}{c}0.102 \\
(1.49)\end{array}$ & $\begin{array}{l}0.399^{\star \star} \\
(2.06)\end{array}$ & $\begin{array}{l}0.268^{\text {***}} \\
(9.95)\end{array}$ \\
\hline FIRM_AGE & $\begin{array}{l}0.047^{* *} \\
(2.53)\end{array}$ & $\begin{array}{r}0.001 \\
(0.02)\end{array}$ & $\begin{array}{l}0.061^{*} \\
(1.79)\end{array}$ & $\begin{array}{l}0.232^{\star \star \star} \\
(2.94)\end{array}$ & $\begin{array}{l}0.045^{* * *} \\
(5.52)\end{array}$ \\
\hline Intercept & $\begin{array}{l}-1.101^{\text {*** }} \\
(2.95)\end{array}$ & $\begin{array}{l}-1.005^{\text {*** }} \\
(3.69)\end{array}$ & $\begin{array}{l}-2.137^{\star \star \star} \\
(3.70)\end{array}$ & $\begin{array}{c}-0.328 \\
(0.67)\end{array}$ & $\begin{array}{l}-1.701^{\text {} \star *} \\
(16.75)\end{array}$ \\
\hline Industry fixed effects & Yes & Yes & Yes & No & No \\
\hline $\begin{array}{l}\text { No. of obs. } \\
\text { Pseudo- } R^{2}\end{array}$ & $\begin{array}{c}88,768 \\
0.07\end{array}$ & $\begin{array}{c}11,436 \\
0.10 \\
\end{array}$ & $\begin{array}{c}37,467 \\
0.06\end{array}$ & $\begin{array}{l}3,842 \\
0.07 \\
\end{array}$ & $\begin{array}{c}84,926 \\
0.06 \\
\end{array}$ \\
\hline
\end{tabular}

spending). ${ }^{7}$ Therefore, we examine whether the negative effect of policy uncertainty on firm acquisitiveness is more pronounced for these firms. We use the data on government contracts, which are available from the year 2000, to estimate firms' sensitivity to government spending. Due to the large government contract data set and the lack of common identifiers between the government contractors and Compustat firms, we use the fuzzy matching method and company names to match government contractors with Compustat firms. We then sort firms into two subgroups based on whether their sales to the government in a given year exceed $\$ 1$ million or not. ${ }^{8}$ We rerun the M\&A probit model separately for the two subgroups and report the results in columns 2 and 3 of Table 3 . The results indicate that the coefficient of policy uncertainty for the subgroup of firms with sales to the government exceeding $\$ 1$ million is negative $(-0.171)$ and highly significant, but the coefficient of policy uncertainty for the subgroup of firms with low or no sales to the government is not significantly different from 0 . This evidence

\footnotetext{
${ }^{7}$ We thank the referee for the suggestion to consider a firm's sales sensitivity to government spending in this analysis.

${ }^{8}$ Our finding persists if we use other contract values or use the ratio of sales to the government to a firm's total sales for classification.
} 
suggests that the negative relationship between policy uncertainty and M\&A acquisitiveness is more pronounced for firms that are more prone to uncertainty related to government spending.

We acknowledge that using fuzzy matching based on company names to match government contractors with Compustat firms may underestimate a firm's sales to the government, particularly when a firm's subsidiary, whose name is different from that of the parent, is also a government contractor. To alleviate this concern, in a complementary analysis, we rerun the M\&A probit model separately for firms in industries that tend to be more dependent on government spending, which include defense, health care, engineering services, and heavy construction (Baker et al. (2016)), and for those in the remaining industries. The results reported in columns 4 and 5 of Table 3 indicate that policy uncertainty has a stronger negative effect on the acquisitiveness of firms in industries that are more dependent on government spending.

In another analysis, we further examine the effect of policy uncertainty on the value of M\&A deals while controlling for acquiring-firm size, market-to-book ratio, financial leverage, GDP growth, yield spread, and CRSP value-weighted index returns. The results indicate a negative relationship between policy uncertainty and M\&A deal value. Our calculation indicates that, holding other variables unchanged at their sample means, a 1-standard-deviation increase in the BBD (2016) index value above its sample mean is associated with a $\$ 30.1$ million decrease in average $M \& A$ deal value (to save space, the estimation results are not reported but are available from the authors).

We investigate the effect of policy uncertainty on the time it takes to complete M\&A deals by running the following ordinary least squares (OLS) model:

(2) TIME_TO_COMPLETION ${ }_{i j}=\alpha+\beta \times \mathrm{PU}_{t-1}+\mathbf{C}_{i, t-1} \times \lambda$

$$
+\gamma \text { INDUSTRY_FIXED_EFFECTS }+\varepsilon_{i, t},
$$

where TIME_TO_COMPLETION is the natural logarithm of 1 plus the number of years it takes for deal $j$ of firm $i$ from its announcement in year $t$ to its completion. $\mathbf{C}$ is a vector of control variables, including SIZE, MARKET-TO-BOOK RATIO, BOOK_LEVERAGE, PAST_12_MONTH_STOCK_RETURNS, FIRM_ AGE, AVERAGE_SALES_GROWTH, NONCASH_WORKING_CAPITAL, EXCESS_CASH, STOCK_DUMMY, CASH_DUMMY, HIGH_TECH_DUMMY, DIVERSIFYING_DUMMY,HOSTILE_DUMMY,PUBLIC_TARGET_DUMMY, and CHALLENGE_DUMMY. We use a subset of the full sample that includes only completed deals in this analysis. The estimation results reported in Table 4 indicate that the coefficient of PU is positive and statistically significant, suggesting that it takes the acquirers more time to complete the M\&A deals amid policy uncertainty.

\section{B. Policy Uncertainty, Payment Considerations, and Bid Premiums}

Policy uncertainty can exacerbate firms' financial constraints and increase their default risk, leading to a higher cost of external financing. As a result, acquirers may find it more difficult and costlier to obtain external funds to support payment for M\&A deals. In addition, policy uncertainty can increase future cash flow volatility, thereby motivating firms to hold cash as a precautionary measure. 
TABLE 4

Policy Uncertainty and Time to Completion of M\&A Deals

\begin{tabular}{|c|c|c|}
\hline Variable & 1 & 2 \\
\hline PU & $\begin{array}{l}0.023^{* *} \\
(2.14)\end{array}$ & $\begin{array}{l}0.029^{\star \star} \\
(2.05)\end{array}$ \\
\hline SIZE & $\begin{array}{l}0.006^{\star \star *} \\
(6.95)\end{array}$ & $\begin{array}{l}0.007^{\star \star \star} \\
(6.54)\end{array}$ \\
\hline MARKET-TO-BOOK_RATIO & $\begin{array}{c}0.001 \\
(0.66)\end{array}$ & $\begin{array}{c}0.001 \\
(0.22)\end{array}$ \\
\hline PAST_12_MONTH_RETURNS & $\begin{array}{c}-0.002 \\
(0.63)\end{array}$ & $\begin{array}{r}-0.001 \\
(0.29)\end{array}$ \\
\hline AVERAGE_SALES_GROWTH & $\begin{array}{l}0.012^{\star \star *} \\
(2.66)\end{array}$ & $\begin{array}{l}0.012^{\star \star} \\
(2.43)\end{array}$ \\
\hline BOOK_LEVERAGE & $\begin{array}{r}0.014 \\
(1.50)\end{array}$ & $\begin{array}{l}0.023^{\star \star} \\
(2.25)\end{array}$ \\
\hline NONCASH_WORKING_CAPITAL & $\begin{array}{c}-0.008 \\
(0.77)\end{array}$ & $\begin{array}{c}-0.01 \\
(0.93)\end{array}$ \\
\hline FIRM_AGE & $\begin{array}{r}0.001 \\
(0.43)\end{array}$ & $\begin{array}{c}0.003 \\
(1.34)\end{array}$ \\
\hline DEAL_RATIO & $\begin{array}{r}0.001 \\
(1.63)\end{array}$ & $\begin{array}{r}0.001 \\
(1.26)\end{array}$ \\
\hline EXCESS_CASH & $\begin{array}{r}0.001 \\
(1.39)\end{array}$ & $\begin{array}{r}0.001 \\
(0.99)\end{array}$ \\
\hline STOCK_DUMMY & $\begin{array}{l}0.057^{\star \star \star} \\
(8.23)\end{array}$ & $\begin{array}{l}0.056^{\star \star \star} \\
(5.80)\end{array}$ \\
\hline CASH_DUMMY & $\begin{array}{c}0.070^{\text {*** }} \\
(17.98)\end{array}$ & $\begin{array}{l}0.072^{\star \star \star} \\
(7.29)\end{array}$ \\
\hline HIGH_TECH_DUMMY & $\begin{array}{c}-0.002 \\
(0.63)\end{array}$ & $\begin{array}{l}-0.007^{\star \star} \\
(2.16)\end{array}$ \\
\hline DIVERSIFYING_DUMMY & $\begin{array}{l}-0.026^{* * *} \\
(8.04)\end{array}$ & 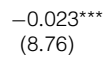 \\
\hline HOSTILE_DUMMY & $\begin{array}{l}0.131^{\text {*** }} \\
(3.80)\end{array}$ & $\begin{array}{l}0.132^{\star \star \star} \\
(4.28)\end{array}$ \\
\hline PUBLIC_TARGET_DUMMY & $\begin{array}{l}0.206^{\star * *} \\
(43.52)\end{array}$ & $\begin{array}{l}0.209^{\star \star \star} \\
(20.63)\end{array}$ \\
\hline CHALLENGE_DUMMY & $\begin{array}{l}-0.166^{\star * *} \\
(18.59)\end{array}$ & $\begin{array}{l}-0.166^{\star \star \star} \\
(13.09)\end{array}$ \\
\hline Intercept & $\begin{array}{c}-0.111^{\star *} \\
(2.06)\end{array}$ & $\begin{array}{c}-0.160^{\star \star} \\
(2.23)\end{array}$ \\
\hline Industry fixed effects & Yes & No \\
\hline $\begin{array}{l}\text { No. of obs. } \\
\text { Adj. } R^{2}\end{array}$ & $\begin{array}{c}14,425 \\
0.23\end{array}$ & $\begin{array}{c}14,425 \\
0.23 \\
\end{array}$ \\
\hline
\end{tabular}

These arguments suggest that acquirers will be less likely to exchange a highly liquid, less risky asset (i.e., cash) for the less liquid, riskier assets (i.e., target firms' hard assets) amid high policy uncertainty. Consistent with this proposition, we expect a positive (negative) relationship between policy uncertainty and stock (cash) payment. We estimate the following payment consideration probit model to examine the effect of policy uncertainty on the method of payment:

$$
\begin{aligned}
\text { STOCK_DUMMY }_{i j}= & \alpha+\beta \times \mathrm{PU}_{t-1}+\mathbf{C}_{i, t-1} \times \lambda \\
& +\gamma \text { INDUSTRY_FIXED_EFFECTS }+\varepsilon_{i, t},
\end{aligned}
$$


where STOCK_DUMMY is an indicator that equals 1 if the payment for M\&A deal $j$ of firm $i$ is fully in stock, and 0 otherwise. $\mathbf{C}$ is a vector of control variables that include firm and deal characteristics.

Because the proportion of stock payment for an M\&A deal ranges from $0 \%$ to $100 \%$, we further estimate the following Tobit model to gauge the effect of PU on the proportion of stock payment:

$$
\text { (4) } \begin{aligned}
\text { STOCK_PROPORTION }_{i j}= & \alpha+\beta \times \mathrm{PU}_{t-1}+\mathbf{C}_{i, t-1} \times \lambda \\
& +\gamma \text { INDUSTRY_FIXED_EFFECTS }+\varepsilon_{i, t} .
\end{aligned}
$$

We report the estimation results of the payment consideration probit and Tobit models in columns 1 and 2, respectively, of Table 5. The coefficients of

\section{TABLE 5}

\begin{tabular}{|c|c|c|}
\hline & Prodit iviodel & lobit Mode \\
\hline Variable & 1 & 2 \\
\hline PU & $\begin{array}{l}0.562^{\star \star} \\
(1.97)\end{array}$ & $\begin{array}{l}0.396^{* *} \\
(2.25)\end{array}$ \\
\hline SIZE & $\begin{array}{c}-0.111^{\star \star \star} \\
(4.52)\end{array}$ & $\begin{array}{c}-0.086^{\star * *} \\
(6.24)\end{array}$ \\
\hline MARKET-TO-BOOK_RATIO & $\begin{array}{l}0.115^{\star \star \star} \\
(3.69)\end{array}$ & $\begin{array}{l}0.080^{\star \star *} \\
(5.25)\end{array}$ \\
\hline PAST_12_MONTH_RETURNS & $\begin{array}{c}-0.034 \\
(0.90)\end{array}$ & $\begin{array}{c}0.005 \\
(0.23)\end{array}$ \\
\hline AVERAGE_SALES_GROWTH & $\begin{array}{l}0.142^{\star \star \star} \\
(2.85)\end{array}$ & $\begin{array}{l}0.147^{\text {***}} \\
(4.19)\end{array}$ \\
\hline BOOK_LEVERAGE & $\begin{array}{r}0.257 \\
(1.40)\end{array}$ & $\begin{array}{r}0.157 \\
(1.34)\end{array}$ \\
\hline NONCASH_WORKING_CAPITAL & $\begin{array}{c}-0.144 \\
(0.75)\end{array}$ & $\begin{array}{c}-0.166^{*} \\
(1.78)\end{array}$ \\
\hline FIRM_AGE & $\begin{array}{c}-0.06 \\
(1.11)\end{array}$ & $\begin{array}{c}-0.066^{* *} \\
(2.43)\end{array}$ \\
\hline DEAL_RATIO & $\begin{array}{c}0.001 \\
(0.45)\end{array}$ & $\begin{array}{c}0.002 \\
(0.70)\end{array}$ \\
\hline EXCESS_CASH & $\begin{array}{c}0.00 \\
(0.94)\end{array}$ & $\begin{array}{c}-0.001^{\star \star} \\
(2.44)\end{array}$ \\
\hline HIGH_TECH_DUMMY & $\begin{array}{l}0.242^{\star \star \star} \\
(4.51)\end{array}$ & $\begin{array}{l}0.193^{* * *} \\
(6.77)\end{array}$ \\
\hline DIVERSIFYING_DUMMY & $\begin{array}{l}0.161^{\star \star \star} \\
(3.32)\end{array}$ & $\begin{array}{l}0.147^{\star \star \star \star} \\
(3.92)\end{array}$ \\
\hline HOSTILE_DUMMY & $\begin{array}{c}0.124 \\
(0.44)\end{array}$ & $\begin{array}{l}0.206 \\
(0.91)\end{array}$ \\
\hline PUBLIC_TARGET_DUMMY & $\begin{array}{l}0.889^{\star \star \star \star} \\
(14.73)\end{array}$ & $\begin{array}{l}0.487^{* * *} \\
(5.45)\end{array}$ \\
\hline CHALLENGE_DUMMY & $\begin{array}{l}-1.022^{\star \star \star \star} \\
(5.39)\end{array}$ & $\begin{array}{l}-0.726^{\star \star \star} \\
(5.80)\end{array}$ \\
\hline Intercept & $\begin{array}{c}-3.059^{\star \star} \\
(2.46)\end{array}$ & $\begin{array}{l}0.809^{\star * *} \\
(42.49)\end{array}$ \\
\hline Industry fixed effects & Yes & Yes \\
\hline $\begin{array}{l}\text { No. of obs. } \\
\text { Pseudo- } R^{2}\end{array}$ & $\begin{array}{l}6,376 \\
0.24\end{array}$ & $\begin{array}{l}6,376 \\
0.15\end{array}$ \\
\hline
\end{tabular}

\section{Policy Uncertainty and Payment Consideration}


PU are positive in both columns ( 0.562 and 0.396 , respectively) and highly significant. This evidence indicates that acquirers are more likely to use stock as M\&A currency during periods of high policy uncertainty, which is consistent with our expectation. The signs and significance of other control variables are qualitatively similar to those reported in the literature. For example, MARKET-TO-BOOK_RATIO and PUBLIC_TARGET_DUMMY (SIZE and FIRM_AGE) are positively (negatively) related to the stock payment likelihood.

We turn next to the relationship between policy uncertainty and the bid premiums, which are measured as the percentage difference between the bid prices and the targets' stock prices 1 week before the deal announcements. Because policy uncertainty can increase the cost of capital and liquidity risk and exacerbate financial constraints, acquirers are expected to be more prudent with M\&A deals, particularly with the bid prices. Moreover, acquirers can negotiate better M\&A deal terms with targets whose operations are adversely affected by policy uncertainty and, thus, would be more willing to accept lower bid prices. These discussions suggest a negative relationship between policy uncertainty and the bid premiums. We run the bid premiums regressions on PU while controlling for other firm and deal characteristics, including SIZE, MARKET-TO-BOOK_RATIO, BOOK_LEVERAGE, PAST_12_MONTH_STOCK_RETURNS, FIRM_AGE, AVERAGE_SALES_GROWTH, NONCASH_WORKING_CAPITAL, EXCESS CASH, STOCK_DUMMY, CASH_DUMMY (the mixed stock-cash payment is left out to avoid perfect collinearity), HIGH_TECH_DUMMY, DIVERSIFYING DUMMY, HOSTILE_DUMMY, PUBLIC_TARGET_DUMMY, and CHALLENGE_DUMMY (Officer (2003), Dimopoulos and Sacchetto (2014)). Columns 1 and 2 of Table 6 report the results of the bid-premium regressions with and without industry fixed effects, respectively. Consistent with our expectation, the coefficients of PU are negative $(-0.462$ and -0.483$)$ and highly significant.

Because the bid premiums can depend on the acquirers' financial status, we additionally run the bid-premium regressions separately for financially constrained and unconstrained subgroups of acquirers. In particular, we sort acquirers with (without) Standard \& Poor's (S\&P) long-term credit ratings into the financially unconstrained (constrained) subgroup. Credit ratings are important for acquiring firms because they typically access the external capital market to raise funds to support M\&A deals. The analysis results reported in columns 3 and 4 of Table 6 suggest that the relationship between PU and the bid premiums is negative and statistically significant (insignificant) for financially constrained (unconstrained) acquirers, implying that acquirers that lack access to the external capital market are more conservative with their bid prices during periods of high policy uncertainty. ${ }^{9}$

\section{Policy Uncertainty and Acquirer Shareholder Value}

We are interested in gauging the effect of policy uncertainty on acquirer shareholder value. Policy uncertainty poses external risk to firm operations in

\footnotetext{
${ }^{9}$ Our results are quantitatively similar if we sort firms with S\&P long-term investment-grade ratings (noninvestment ratings and no ratings) into the financially unconstrained (constrained) subgroup.
} 
TABLE 6

\section{Policy Uncertainty and Bid Premiums}

Table 6 reports the bid-premium OLS regressions. The dependent variable is BID_PREMIUMS, which is measured as the percentage difference between the bidding price and the target stock price 1 week prior to an M\&A announcement. PU is the natural logarithm of the weighted average of the Baker, Bloom, and Davis (BBD) (2016) policy uncertainty index over the 3-month period at the end of the fiscal year preceding the M\&A announcement. Other variables are defined in the Appendix. $t$-statistics based on heteroscedasticity-robust standard errors clustered by years are reported in parentheses. ${ }^{*},{ }^{\star \star}$, and ${ }^{* \star *}$ indicate significance at the $10 \%, 5 \%$, and $1 \%$ levels, respectively.

Dependent Variable: BID_PREMIUMS

\begin{tabular}{|c|c|c|c|c|}
\hline Variable & 1 & 2 & 3 & 4 \\
\hline PU & $\begin{array}{l}-0.462^{\star \star} \\
(1.97)\end{array}$ & $\begin{array}{l}-0.483^{\star \star} \\
(2.05)\end{array}$ & $\begin{array}{l}-0.678^{\star \star} \\
(2.18)\end{array}$ & $\begin{array}{c}-0.198 \\
(1.15)\end{array}$ \\
\hline SIZE & $\begin{array}{r}0.017 \\
(0.56)\end{array}$ & $\begin{array}{c}0.010 \\
(0.29)\end{array}$ & $\begin{array}{c}-0.025 \\
(0.44)\end{array}$ & $\begin{array}{c}0.016 \\
(0.34)\end{array}$ \\
\hline MARKET-TO-BOOK_RATIO & $\begin{array}{c}0.017 \\
(0.56)\end{array}$ & $\begin{array}{c}0.033 \\
(1.08)\end{array}$ & $\begin{array}{c}0.038 \\
(1.19)\end{array}$ & $\begin{array}{c}-0.008 \\
(0.17)\end{array}$ \\
\hline PAST_12_MONTH_RETURNS & $\begin{array}{c}0.058 \\
(0.68)\end{array}$ & $\begin{array}{c}0.026 \\
(0.35)\end{array}$ & $\begin{array}{r}-0.017 \\
(0.16)\end{array}$ & $\begin{array}{c}0.15 \\
(1.23)\end{array}$ \\
\hline AVERAGE_SALES_GROWTH & $\begin{array}{c}0.125 \\
(0.96)\end{array}$ & $\begin{array}{c}0.137 \\
(1.10)\end{array}$ & $\begin{array}{c}0.060 \\
(0.37)\end{array}$ & $\begin{array}{c}0.166 \\
(0.83)\end{array}$ \\
\hline BOOK_LEVERAGE & $\begin{array}{l}0.512^{\star} \\
(1.82)\end{array}$ & $\begin{array}{c}0.273 \\
(1.02)\end{array}$ & $\begin{array}{c}0.48 \\
(1.16)\end{array}$ & $\begin{array}{l}0.398 \\
(0.94)\end{array}$ \\
\hline NONCASH_WORKING_CAPITAL & $\begin{array}{c}0.294 \\
(0.74)\end{array}$ & $\begin{array}{c}-0.024 \\
(0.09)\end{array}$ & $\begin{array}{c}0.422 \\
(0.61)\end{array}$ & $\begin{array}{c}0.112 \\
(0.27)\end{array}$ \\
\hline FIRM_AGE & $\begin{array}{c}-0.105 \\
(1.15)\end{array}$ & $\begin{array}{c}-0.123 \\
(1.29)\end{array}$ & $\begin{array}{c}-0.207^{*} \\
(1.80)\end{array}$ & $\begin{array}{r}-0.007 \\
(0.07)\end{array}$ \\
\hline EXCESS_CASH & $\begin{array}{r}0.001 \\
(0.69)\end{array}$ & $\begin{array}{r}0.001 \\
(0.33)\end{array}$ & $\begin{array}{r}0.001 \\
(0.31)\end{array}$ & $\begin{array}{l}0.378 \\
(0.93)\end{array}$ \\
\hline DEAL_RATIO & $\begin{array}{l}0.028^{\star \star \star} \\
(3.31)\end{array}$ & $\begin{array}{l}0.030^{\star \star \star} \\
(3.87)\end{array}$ & $\begin{array}{c}0.124 \\
(1.21)\end{array}$ & $\begin{array}{l}0.018^{\star} \\
(2.03)\end{array}$ \\
\hline STOCK_DUMMY & $\begin{array}{r}-0.027 \\
(0.23)\end{array}$ & $\begin{array}{c}0.059 \\
(0.54)\end{array}$ & $\begin{array}{c}0.048 \\
(0.26)\end{array}$ & $\begin{array}{c}-0.185 \\
(1.17)\end{array}$ \\
\hline CASH_DUMMY & $\begin{array}{l}-0.389^{\star \star \star} \\
(2.88)\end{array}$ & $\begin{array}{l}-0.404^{\star \star \star} \\
(2.81)\end{array}$ & $\begin{array}{c}-0.349 \\
(1.58)\end{array}$ & $\begin{array}{l}-0.391^{\star \star} \\
(2.66)\end{array}$ \\
\hline DIVERSIFYING_DUMMY & 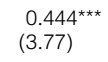 & $\begin{array}{l}0.414^{\star \star \star} \\
(3.74)\end{array}$ & $\begin{array}{l}0.446^{\text {*** }} \\
(2.77)\end{array}$ & $\begin{array}{l}0.415^{\star \star \star} \\
(3.54)\end{array}$ \\
\hline HOSTILE_DUMMY & $\begin{array}{l}0.308^{\star \star} \\
(2.27)\end{array}$ & $\begin{array}{l}0.445^{\star \star \star} \\
(3.31)\end{array}$ & $\begin{array}{r}0.317 \\
(1.32)\end{array}$ & $\begin{array}{c}0.103 \\
(0.45)\end{array}$ \\
\hline PUBLIC_TARGET_DUMMY & $\begin{array}{l}0.080 \\
(0.17)\end{array}$ & $\begin{array}{c}0.122 \\
(0.34)\end{array}$ & $\begin{array}{c}-0.756 \\
(0.60)\end{array}$ & $\begin{array}{c}0.282 \\
(0.65)\end{array}$ \\
\hline CHALLENGE_DUMMY & $\begin{array}{l}0.549^{\star \star \star} \\
(4.75)\end{array}$ & $\begin{array}{l}0.549^{\star \star \star} \\
(4.81)\end{array}$ & $\begin{array}{l}0.516^{\text {** }} \\
(3.58)\end{array}$ & $\begin{array}{l}0.633^{\star \star \star} \\
(4.54)\end{array}$ \\
\hline Intercept & $\begin{array}{l}1.443 \\
(1.09)\end{array}$ & $\begin{array}{l}0.718 \\
(0.57)\end{array}$ & $\begin{array}{c}2.578 \\
(1.10)\end{array}$ & $\begin{array}{c}0.15 \\
(0.15)\end{array}$ \\
\hline Industry fixed effects & Yes & No & Yes & Yes \\
\hline $\begin{array}{l}\text { No. of obs. } \\
\text { Adj. } R^{2}\end{array}$ & $\begin{array}{l}1,060 \\
0.13\end{array}$ & $\begin{array}{l}1,060 \\
0.11\end{array}$ & $\begin{array}{l}556 \\
0.14\end{array}$ & $\begin{array}{l}504 \\
0.13\end{array}$ \\
\hline \multicolumn{5}{|c|}{ Test of difference in coefficients of PU of the two subgroups: } \\
\hline \multicolumn{3}{|l|}{$\begin{array}{l}\chi^{2} \\
p \text {-value }\end{array}$} & $\begin{array}{c}13.4 \\
0.00 \\
\end{array}$ & \\
\hline
\end{tabular}

general and could complicate and amplify the risk of large investments such as M\&As in particular, potentially leading to a decrease in acquirer shareholder value. However, as firms become more prudent and delay large and risky investments during periods of high uncertainty (Bernanke (1983), Rodrik (1991), Bloom et al. (2007), Baker et al. (2016), and Gulen and Ion (2016)), acquirers are likely to choose to pursue those M\&A deals that have better expected 
outcomes, which implies a positive relationship between policy uncertainty and acquirer shareholder value. Given the possible opposing effects of policy uncertainty on acquirer shareholder value, we will need to sort them out empirically.

We run cross-sectional regressions of the acquirer 3-day CARs centered on the deal announcement day. Acquirer CARs are estimated using the market model and the value-weighted CRSP index returns as a proxy for market returns. Following earlier studies (e.g., Harford (1999), Moeller, Schlingemann, and Stulz (2005), and Masulis, Wang, and Xie (2007)), we control for the following firm and deal characteristics in our cross-sectional regressions: SIZE, MARKET-TOBOOK_RATIO, BOOK_LEVERAGE, EXCESS_CASH, PAST_12_MONTH_ RETURNS, HIGH_TECH_DUMMY, CASH_DUMMY, STOCK_DUMMY, HOSTILE_DUMMY, PUBLIC_TARGET_DUMMY, TARGET_INDUSTRY M\&A_INTENSITY, and CHALLENGE_DUMMY. The definitions of the variables are provided in the Appendix. It is possible that the CAR cross-sectional regressions are prone to self-selection bias because M\&As are managers' decisions rather than a random assignment. To address the self-selection bias concern, we use the Heckman (1976), (1979) 2-step self-selection correction model for estimation. Specifically, we include the inverse Mill's ratio (IMR), which is calculated using the coefficient estimates of the M\&A probit model, as an additional control variable in some cross-sectional regression specifications.

We report the results of the acquirer CAR cross-sectional regressions in columns 1 and 2 of Table 7. The coefficients of PU are positive (0.015) and statistically significant at the $1 \%$ level, indicating a positive relationship between policy uncertainty and acquirer shareholder value. The value effect of PU is economically important. Our point estimates indicate that, holding other variables unchanged at their sample means, a 1-standard-deviation increase in PU above its sample mean is associated with an increase of $70 \mathrm{bps}$ (i.e., $0.7 \%$ ), which is equivalent to $\$ 31.4$ million, in acquirer shareholder value over the 3-day window centered on the M\&A announcement day. The effects of other control variables on acquirer CARs are in line with those reported in the literature. For instance, we observe positive (negative) relationships between acquirer CARs and BOOK_LEVERAGE, FIRM_AGE, and CASH_DUMMY (SIZE, MARKET-TOBOOK_RATIO, and PUBLIC_TARGET_DUMMY). Finally, our finding is not sensitive to the correction for self-selection bias.

It is worth noting that the level of policy uncertainty may change during the period from the end of the year preceding an M\&A announcement to the actual announcement day. Therefore, in a robustness check, we run the acquirer CAR cross-sectional regressions with an alternative version of the policy uncertainty variable, labeled PU_ANNOUNCEMENT, which is measured as the natural logarithm of the weighted average of the BBD (2016) index of the 3-month period preceding the M\&A announcement day, and report the results in columns 3 and 4 of Table 7. The coefficients of PU_ANNOUNCEMENT are positive (0.007) and statistically significant, suggesting that our results are robust to this alternative measure of policy uncertainty.

In addition to the acquirers' prudence with M\&As, another possible explanation for the positive relationship between policy uncertainty and acquirer shareholder value around the deal announcements is the value transfer from the 
TABLE 7

Policy Uncertainty and Acquirer CARs

Table 7 reports the acquirer CAR cross-sectional regressions. The dependent variable is the acquirer 3-day CARs centered on the M\&A announcement day. PU is the natural logarithm of the weighted average of the Baker, Bloom, and Davis (BBD) (2016) policy uncertainty index over the 3-month period at the end of the fiscal year preceding the M\&A announcement. PU ANNOUNCEMENT is the natural logarithm of the weighted average of the BBD index over the 3-month period preceding the deal announcement. IMR is the inverse Mills ratio. Other variables are defined in the Appendix. $t$-statistics based on heteroscedasticity-robust standard errors clustered by years are reported in parentheses. ${ }^{*}$ **, and ${ }^{* \star *}$ indicate significance at the $10 \%, 5 \%$, and $1 \%$ levels, respectively.

\begin{tabular}{|c|c|c|c|c|}
\hline \multirow[b]{2}{*}{ Variable } & \multicolumn{4}{|c|}{ Dependent Variable: CAR $(-1,+1)$} \\
\hline & 1 & 2 & 3 & 4 \\
\hline PU & $\begin{array}{l}0.015^{\star \star *} \\
(3.34)\end{array}$ & $\begin{array}{l}0.015^{\text {** }} \\
(2.91)\end{array}$ & & \\
\hline PU_ANNOUNCEMENT & & & $\begin{array}{l}0.007^{\star \star} \\
(2.04)\end{array}$ & $\begin{array}{l}0.007^{\star} \\
(1.91)\end{array}$ \\
\hline SIZE & $\begin{array}{c}-0.008^{\star * *} \\
(8.34)\end{array}$ & $\begin{array}{l}-0.008^{* * *} \\
(4.73)\end{array}$ & $\begin{array}{l}-0.007^{\star \star \star *} \\
(8.40)\end{array}$ & $\begin{array}{l}-0.007^{\text {ᄎ**}} \\
(4.77)\end{array}$ \\
\hline MARKET-TO-BOOK_RATIO & $\begin{array}{l}-0.002^{\star *} \\
(2.34)\end{array}$ & $\begin{array}{c}-0.003^{\star *} \\
(2.25)\end{array}$ & $\begin{array}{l}-0.003^{\star \star} \\
(2.57)\end{array}$ & $\begin{array}{c}-0.003^{\star \star} \\
(2.19)\end{array}$ \\
\hline PAST_12_MONTH_RETURNS & $\begin{array}{c}-0.002 \\
(0.94)\end{array}$ & $\begin{array}{c}-0.002 \\
(0.87)\end{array}$ & $\begin{array}{c}-0.003 \\
(1.06)\end{array}$ & $\begin{array}{c}-0.002 \\
(0.88)\end{array}$ \\
\hline AVERAGE_SALES_GROWTH & $\begin{array}{c}-0.006 \\
(1.02)\end{array}$ & $\begin{array}{c}-0.006 \\
(1.03)\end{array}$ & $\begin{array}{c}-0.006 \\
(1.04)\end{array}$ & $\begin{array}{c}-0.006 \\
(1.04)\end{array}$ \\
\hline BOOK_LEVERAGE & $\begin{array}{l}0.023^{\star * *} \\
(3.96)\end{array}$ & $\begin{array}{l}0.023^{\star \star \star} \\
(2.86)\end{array}$ & $\begin{array}{l}0.022^{\star \star \star} \\
(3.94)\end{array}$ & $\begin{array}{l}0.021^{\star \star} \\
(2.74)\end{array}$ \\
\hline NONCASH_WORKING_CAPITAL & $\begin{array}{c}0.017^{\star} \\
(1.72)\end{array}$ & $\begin{array}{l}0.017^{*} \\
(1.73)\end{array}$ & $\begin{array}{c}0.016 \\
(1.60)\end{array}$ & $\begin{array}{c}0.016 \\
(1.70)\end{array}$ \\
\hline FIRM_AGE & $\begin{array}{l}0.006^{\star * *} \\
(2.80)\end{array}$ & $\begin{array}{l}0.006^{\text {*** }} \\
(2.93)\end{array}$ & $\begin{array}{l}0.006^{\star \star} \\
(2.72)\end{array}$ & $\begin{array}{l}0.007^{\star \star \star} \\
(2.84)\end{array}$ \\
\hline EXCESS_CASH & $\begin{array}{l}0.001^{\star * \star} \\
(5.09)\end{array}$ & $\begin{array}{l}0.001^{\star \star \star} \\
(5.09)\end{array}$ & $\begin{array}{l}0.001^{\star \star \star} \\
(4.93)\end{array}$ & $\begin{array}{l}0.001^{\star \star \star} \\
(4.92)\end{array}$ \\
\hline DEAL_RATIO & $\begin{array}{r}0.001 \\
(1.42)\end{array}$ & $\begin{array}{r}0.001 \\
(1.42)\end{array}$ & $\begin{array}{r}0.001 \\
(1.44)\end{array}$ & $\begin{array}{r}0.001 \\
(1.44)\end{array}$ \\
\hline STOCK_DUMMY & $\begin{array}{c}-0.002 \\
(0.48)\end{array}$ & $\begin{array}{c}-0.002 \\
(0.49)\end{array}$ & $\begin{array}{c}-0.002 \\
(0.66)\end{array}$ & $\begin{array}{c}-0.002 \\
(0.64)\end{array}$ \\
\hline CASH_DUMMY & $\begin{array}{l}0.008^{\star \star *} \\
(3.94)\end{array}$ & $\begin{array}{l}0.008^{\text {** }} \\
(3.90)\end{array}$ & $\begin{array}{l}0.008^{\star \star \star} \\
(4.36)\end{array}$ & $\begin{array}{l}0.008^{\star \star \star} \\
(4.37)\end{array}$ \\
\hline HIGH_TECH_DUMMY & $\begin{array}{l}-0.007^{* *} \\
(2.19)\end{array}$ & $\begin{array}{l}-0.007^{\text {** }}(2.27)\end{array}$ & $\begin{array}{l}-0.007^{\star \star} \\
(2.21)\end{array}$ & $\begin{array}{l}-0.007^{\star \star} \\
(2.23)\end{array}$ \\
\hline DIVERSIFYING_DUMMY & $\begin{array}{c}-0.001 \\
(0.31)\end{array}$ & $\begin{array}{c}-0.001 \\
(0.31)\end{array}$ & $\begin{array}{r}-0.001 \\
(0.44)\end{array}$ & $\begin{array}{r}-0.001 \\
(0.44)\end{array}$ \\
\hline HOSTILE_DUMMY & $\begin{array}{c}-0.019 \\
(1.29)\end{array}$ & $\begin{array}{c}-0.019 \\
(1.29)\end{array}$ & $\begin{array}{c}-0.02 \\
(1.39)\end{array}$ & $\begin{array}{c}-0.02 \\
(1.39)\end{array}$ \\
\hline PUBLIC_TARGET_DUMMY & $\begin{array}{c}-0.018^{* * *} \\
(4.81)\end{array}$ & $\begin{array}{l}-0.018^{\star * \star} \\
(4.80)\end{array}$ & 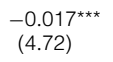 & $\begin{array}{l}-0.017^{\text {*** }}(4.71)\end{array}$ \\
\hline CHALLENGE_DUMMY & $\begin{array}{l}0.016^{\text {** }} \\
(2.45)\end{array}$ & $\begin{array}{l}0.016^{\star *} \\
(2.45)\end{array}$ & $\begin{array}{l}0.015^{\star *} \\
(2.30)\end{array}$ & $\begin{array}{l}0.015^{\star \star} \\
(2.31)\end{array}$ \\
\hline TARGET_INDUSTRY_M\&A_INTENSITY & $\begin{array}{c}0.001 \\
(0.60)\end{array}$ & $\begin{array}{c}0.001 \\
(0.61)\end{array}$ & $\begin{array}{c}0.001 \\
(0.57)\end{array}$ & $\begin{array}{c}0.001 \\
(0.56)\end{array}$ \\
\hline IMR & & $\begin{array}{c}-0.003 \\
(0.25)\end{array}$ & & $\begin{array}{c}0.003 \\
(0.32)\end{array}$ \\
\hline Intercept & $\begin{array}{c}-0.023 \\
(0.95)\end{array}$ & $\begin{array}{c}-0.019 \\
(0.94)\end{array}$ & $\begin{array}{c}0.012 \\
(0.74)\end{array}$ & $\begin{array}{c}0.008 \\
(0.37)\end{array}$ \\
\hline $\begin{array}{l}\text { No. of obs. } \\
\text { Adj. } R^{2}\end{array}$ & $\begin{array}{l}6,376 \\
0.03\end{array}$ & $\begin{array}{l}6,376 \\
0.03\end{array}$ & $\begin{array}{l}6,376 \\
0.03\end{array}$ & $\begin{array}{l}6,376 \\
0.03\end{array}$ \\
\hline
\end{tabular}

acquisition targets to the acquirers. The reason is that policy uncertainty can have adverse effects on the target firms' operations, particularly those of financially constrained firms, weakening their bargaining power. Therefore, we predict a negative relationship between policy uncertainty and the target announcement CARs. We run the target CAR cross-sectional regressions and report the results 
in Table 8. The negative $(-0.029)$ and significant coefficient of PU suggests that policy uncertainty adversely affects target shareholder value. The estimation results indicate that, holding other variables unchanged at their sample means, a 1-standard-deviation increase in PU above its sample mean is associated with a decrease of 96 bps (i.e., $0.96 \%$ ) or $\$ 43.2$ million in target shareholder value over a

TABLE 8

Policy Uncertainty and Target CARs

Table 8 reports the target CAR cross-sectional regressions. The dependent variable is the target 3-day CARs centered on the M\&A announcement day. PU is the natural logarithm of the weighted average of the policy uncertainty index over the 3-month period at the end of the fiscal year preceding the M\&A announcement. The financially unconstrained (constrained) subgroup includes firms with (without) S\&P long-term credit ratings. Other variables are defined in the Appendix. $t$-statistics based on heteroscedasticity-robust standard errors clustered by years are reported in parentheses. ${ }^{*},{ }^{\star *}$, and ${ }^{* *}$ indicate significance at the $10 \%, 5 \%$, and $1 \%$ levels, respectively.

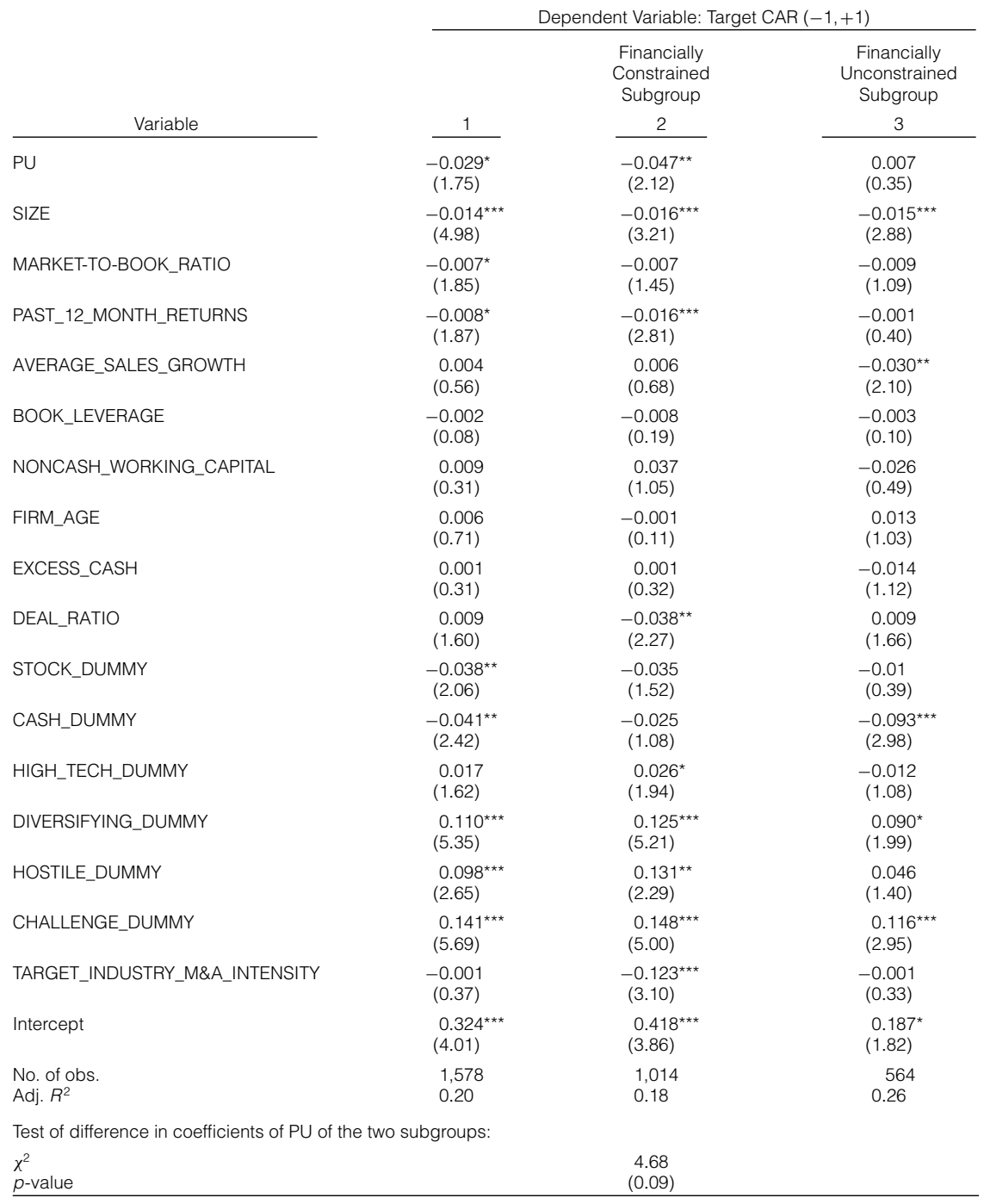


3-day window around the M\&A announcement. This evidence is consistent with our prediction of the value transfer from target to acquirer shareholders as a result of policy uncertainty.

In an additional analysis, we run the target CAR cross-sectional regressions separately for financially constrained and unconstrained target subgroups based on the targets' S\&P long-term credit ratings. The financially unconstrained (constrained) subgroup includes firms that have S\&P long-term credit ratings (no ratings). The regression results reported in columns 2 and 3 of Table 8 indicate that the negative effect of PU on target shareholder value is statistically significant (insignificant) for financially constrained (unconstrained) targets, suggesting that policy uncertainty is particularly harmful for financially constrained target firms. ${ }^{10}$

Next, we examine the effect of policy uncertainty on acquirer long-term stock performance measured by the BHARs using the matched firm-adjusted method (Barber and Lyon (1996), Lyon et al. (1999)). In particular, for each sample acquirer, we identify a matched firm in the same 2-digit SIC code industry that has a size within $70 \%-130 \%$ of the size of the sample firm, has not engaged in any M\&A deal over the last 3 years, and has the closest market-to-book ratio to that of the acquirer. The BHAR is the difference between the buy-and-hold returns of a sample firm and that of the matched firm over the 1-, 2-, and 3-year periods following an M\&A deal completion.

We run cross-sectional regressions to examine the effect of policy uncertainty on acquirer BHARs. Following the literature, we control for firm and deal characteristics including SIZE, MARKET-TO-BOOK_RATIO, BOOK_LEVERAGE, PAST_12_MONTH_RETURNS, AVERAGE_SALES_GROWTH, FIRM_AGE, CASH_DUMMY, STOCK_DUMMY, DEAL_RATIO, DIVERSIFYING DUMMY, and CHALLENGE_DUMMY. The BHAR cross-sectional regression results reported in columns 1-3 of Table 9 show that the coefficients of PU are positive $(0.114,0.109$, and 0.149 for the $1-, 2-$, and 3 -year periods, respectively, following the deal completion) and statistically significant, suggesting that acquirer postacquisition long-term stock performance is positively related to preacquisition policy uncertainty.

The window of time from an M\&A announcement to its completion could range from a few months to a couple of years, and the BBD (2016) index values may change significantly over the same period. Thus, in an alternative specification, we rerun the BHAR cross-sectional regressions with the PU_COMPLETION variable, which is calculated as the natural logarithm of the weighted average of the BBD index over the 3-month period before the M\&A deal completion, and report the results in columns 4-6 of Table 9. The coefficients of PU_COMPLETION are all positive $(0.106,0.102$, and 0.140 in 1-, 2-, and 3-year BHAR regressions, respectively) and statistically significant, suggesting that our finding is robust to this alternative measure of policy uncertainty.

\footnotetext{
${ }^{10}$ In an unreported analysis, we further examine the effect of policy uncertainty on the valueweighted CARs of an acquirer and its target, which proxies for the market assessment of the acquisition synergies. The weights are based on the relative market value of the acquirer and the target at the end of the year preceding the M\&A announcements. However, the analysis result is inconclusive.
} 
TABLE 9

Policy Uncertainty and Acquirer Long-Term Stock Performance

Table 9 reports the acquirer BHAR cross-sectional regression results. The dependent variables are the acquirer 1-, 2-, and 3-year BHARs. PU is the natural logarithm of the weighted average of the Baker, Bloom, and Davis (BBD) (2016) policy uncertainty index over the 3-month period at the end of the fiscal year preceding the M\&A announcement. PU_COMPLETION is the natural logarithm of the weighted average of the BBD policy uncertainty index over the 3-month period preceding the deal completion. Other variables are defined in the Appendix. $t$-statistics based on heteroscedasticityrobust standard errors clustered by years are reported in parentheses. ${ }^{*},{ }^{* *}$, and ${ }^{* *}$ indicate significance at the $10 \%$, $5 \%$, and $1 \%$ levels, respectively.

Dependent Variable: BHARs

\begin{tabular}{|c|c|c|c|c|c|c|}
\hline Variable & $\begin{array}{c}1 \text {-Year } \\
1\end{array}$ & $\begin{array}{c}\text { 2-Year } \\
2 \\
\end{array}$ & $\begin{array}{c}\text { 3-Year } \\
3 \\
\end{array}$ & $\begin{array}{c}\text { 1-Year } \\
4 \\
\end{array}$ & $\begin{array}{c}\text { 2-Year } \\
5 \\
\end{array}$ & $\begin{array}{c}\text { 3-Year } \\
6 \\
\end{array}$ \\
\hline PU & $\begin{array}{l}0.114^{*} \\
(1.86)\end{array}$ & $\begin{array}{l}0.109^{\star \star} \\
(2.36)\end{array}$ & $\begin{array}{l}0.149^{\star \star \star} \\
(2.57)\end{array}$ & & & \\
\hline PU_COMPLETION & & & & $\begin{array}{l}0.106^{*} \\
(1.72)\end{array}$ & $\begin{array}{l}0.102^{\star \star} \\
(2.26)\end{array}$ & $\begin{array}{l}0.140^{\star \star} \\
(2.49)\end{array}$ \\
\hline SIZE & $\begin{array}{l}0.003 \\
(0.51)\end{array}$ & $\begin{array}{l}0.003 \\
(0.26)\end{array}$ & $\begin{array}{c}-0.013 \\
(1.33)\end{array}$ & $\begin{array}{r}0.001 \\
(0.19)\end{array}$ & $\begin{array}{l}0.003 \\
(0.26)\end{array}$ & $\begin{array}{c}-0.013 \\
(1.32)\end{array}$ \\
\hline $\begin{array}{l}\text { MARKET-TO-BOOK_ } \\
\text { RATIO }\end{array}$ & $\begin{array}{l}0.008 \\
(0.85)\end{array}$ & $\begin{array}{c}0.007 \\
(0.47)\end{array}$ & $\begin{array}{c}0.001 \\
(0.03)\end{array}$ & $\begin{array}{l}0.008 \\
(0.98)\end{array}$ & $\begin{array}{c}0.007 \\
(0.47)\end{array}$ & $\begin{array}{r}0.001 \\
(0.03)\end{array}$ \\
\hline $\begin{array}{l}\text { PAST_12_MONTH_ } \\
\text { RETURNS }\end{array}$ & $\begin{array}{l}0.029^{*} \\
(1.75)\end{array}$ & $\begin{array}{l}0.053^{* * *} \\
(3.45)\end{array}$ & $\begin{array}{l}0.064^{* *} \\
(2.41)\end{array}$ & $\begin{array}{l}0.029^{*} \\
(1.67)\end{array}$ & $\begin{array}{l}0.053^{\star \star \star} \\
(3.42)\end{array}$ & $\begin{array}{l}0.063^{\star \star} \\
(2.37)\end{array}$ \\
\hline $\begin{array}{l}\text { AVERAGE_SALES_ } \\
\text { GROWTH }\end{array}$ & $\begin{array}{l}0.017 \\
(0.44)\end{array}$ & $\begin{array}{r}-0.057 \\
(1.68)\end{array}$ & $\begin{array}{r}-0.054 \\
(1.15)\end{array}$ & $\begin{array}{l}0.023 \\
(0.85)\end{array}$ & $\begin{array}{r}-0.056 \\
(1.68)\end{array}$ & $\begin{array}{c}-0.054 \\
(1.15)\end{array}$ \\
\hline BOOK_LEVERAGE & $\begin{array}{c}0.087 \\
(1.37)\end{array}$ & $\begin{array}{l}0.036 \\
(0.41)\end{array}$ & $\begin{array}{r}0.137 \\
(1.07)\end{array}$ & $\begin{array}{l}0.098^{*} \\
(1.69)\end{array}$ & $\begin{array}{c}0.04 \\
(0.42)\end{array}$ & $\begin{array}{c}0.138 \\
(1.08)\end{array}$ \\
\hline $\begin{array}{l}\text { NONCASH_WORKING_ } \\
\text { CAPITAL }\end{array}$ & $\begin{array}{r}-0.011 \\
(0.26)\end{array}$ & $\begin{array}{c}-0.023 \\
(0.56)\end{array}$ & $\begin{array}{r}-0.037 \\
(0.59)\end{array}$ & $\begin{array}{c}-0.025 \\
(0.39)\end{array}$ & $\begin{array}{c}-0.023 \\
(0.55)\end{array}$ & $\begin{array}{c}-0.036 \\
(0.57)\end{array}$ \\
\hline FIRM_AGE & $\begin{array}{c}0.002 \\
(0.13)\end{array}$ & $\begin{array}{l}-0.043^{*} \\
(1.80)\end{array}$ & $\begin{array}{c}-0.02 \\
(0.54)\end{array}$ & $\begin{array}{c}0.002 \\
(0.14)\end{array}$ & $\begin{array}{l}-0.042^{\star} \\
(1.79)\end{array}$ & $\begin{array}{c}-0.02 \\
(0.53)\end{array}$ \\
\hline EXCESS_CASH & $\begin{array}{l}0.000 \\
(0.23)\end{array}$ & $\begin{array}{r}0.000 \\
(0.25)\end{array}$ & $\begin{array}{r}0.001 \\
(1.11)\end{array}$ & $\begin{array}{l}0.001 \\
(0.45)\end{array}$ & $\begin{array}{r}0.001 \\
(0.26)\end{array}$ & $\begin{array}{r}0.001 \\
(1.12)\end{array}$ \\
\hline DEAL_RATIO & $\begin{array}{c}0.001 \\
(1.70)\end{array}$ & $\begin{array}{r}0.001 \\
(0.48)\end{array}$ & $\begin{array}{c}0.002 \\
(0.87)\end{array}$ & $\begin{array}{l}0.001 \\
(0.34)\end{array}$ & $\begin{array}{l}0.001 \\
(0.47)\end{array}$ & $\begin{array}{c}0.002 \\
(0.86)\end{array}$ \\
\hline STOCK_DUMMY & $\begin{array}{r}-0.017 \\
(0.51)\end{array}$ & $\begin{array}{l}0.002 \\
(0.05)\end{array}$ & $\begin{array}{c}0.03 \\
(0.47)\end{array}$ & $\begin{array}{c}-0.012 \\
(0.33)\end{array}$ & $\begin{array}{l}0.003 \\
(0.05)\end{array}$ & $\begin{array}{c}0.03 \\
(0.48)\end{array}$ \\
\hline CASH_DUMMY & $\begin{array}{c}0.023 \\
(1.13)\end{array}$ & $\begin{array}{c}0.04 \\
(0.92)\end{array}$ & $\begin{array}{l}0.084^{\star *} \\
(2.08)\end{array}$ & $\begin{array}{l}0.023 \\
(1.04)\end{array}$ & $\begin{array}{c}0.04 \\
(0.93)\end{array}$ & $\begin{array}{l}0.084^{\star \star} \\
(2.09)\end{array}$ \\
\hline HIGH_TECH_DUMMY & $\begin{array}{l}0.006 \\
(0.24)\end{array}$ & $\begin{array}{l}-0.067^{\star \star} \\
(2.49)\end{array}$ & $\begin{array}{c}0.006 \\
(0.17)\end{array}$ & $\begin{array}{c}0.007 \\
(0.33)\end{array}$ & $\begin{array}{l}-0.066^{\star *} \\
(2.49)\end{array}$ & $\begin{array}{r}0.006 \\
(0.18)\end{array}$ \\
\hline $\begin{array}{l}\text { DIVERSIFYING_ } \\
\text { DUMMY }\end{array}$ & $\begin{array}{r}-0.024 \\
(1.33)\end{array}$ & $\begin{array}{c}-0.055^{\star} \\
(2.00)\end{array}$ & $\begin{array}{l}-0.077^{\star \star} \\
(2.19)\end{array}$ & $\begin{array}{c}-0.023 \\
(1.10)\end{array}$ & $\begin{array}{c}-0.055^{\star} \\
(2.01)\end{array}$ & $\begin{array}{l}-0.077^{\star \star} \\
(2.19)\end{array}$ \\
\hline HOSTILE_DUMMY & $\begin{array}{r}-0.041 \\
(0.35)\end{array}$ & $\begin{array}{l}0.036 \\
(0.23)\end{array}$ & $\begin{array}{l}0.016 \\
(0.12)\end{array}$ & $\begin{array}{c}-0.042 \\
(0.25)\end{array}$ & $\begin{array}{l}0.035 \\
(0.23)\end{array}$ & $\begin{array}{l}0.015 \\
(0.12)\end{array}$ \\
\hline $\begin{array}{l}\text { PUBLIC_TARGET_ } \\
\text { DUMMY }\end{array}$ & $\begin{array}{r}-0.014 \\
(0.60)\end{array}$ & $\begin{array}{c}-0.028 \\
(0.65)\end{array}$ & $\begin{array}{c}-0.03 \\
(0.46)\end{array}$ & $\begin{array}{r}-0.017 \\
(0.57)\end{array}$ & $\begin{array}{c}-0.028 \\
(0.65)\end{array}$ & $\begin{array}{c}-0.03 \\
(0.46)\end{array}$ \\
\hline $\begin{array}{l}\text { CHALLENGE } \\
\text { DUMMY }\end{array}$ & $\begin{array}{c}-0.009 \\
(0.28)\end{array}$ & $\begin{array}{r}0.064 \\
(0.91)\end{array}$ & $\begin{array}{r}0.075 \\
(1.03)\end{array}$ & $\begin{array}{c}-0.008 \\
(0.14)\end{array}$ & $\begin{array}{l}0.065 \\
(0.92)\end{array}$ & $\begin{array}{c}0.075 \\
(1.05)\end{array}$ \\
\hline $\begin{array}{l}\text { TARGET_INDUSTRY } \\
\text { M\&A_INTENSITY }\end{array}$ & $\begin{array}{c}0.021 \\
(0.91)\end{array}$ & $\begin{array}{c}0.074 \\
(0.72)\end{array}$ & $\begin{array}{l}0.271^{\star *} \\
(2.12)\end{array}$ & $\begin{array}{c}-0.018 \\
(0.08)\end{array}$ & $\begin{array}{c}0.07 \\
(0.71)\end{array}$ & $\begin{array}{l}0.270^{\star *} \\
(2.11)\end{array}$ \\
\hline Intercept & $\begin{array}{r}-0.603 \\
(1.34)\end{array}$ & $\begin{array}{c}-0.415^{\star} \\
(1.69)\end{array}$ & $\begin{array}{l}-0.591^{*} \\
(1.90)\end{array}$ & $\begin{array}{c}-0.677 \\
(1.47)\end{array}$ & $\begin{array}{l}(0.39) \\
(1.58)\end{array}$ & $\begin{array}{c}-0.549^{\star} \\
(1.79)\end{array}$ \\
\hline $\begin{array}{l}\text { No. of obs. } \\
\text { Adj. } R^{2}\end{array}$ & $\begin{array}{l}4,481 \\
0.01\end{array}$ & $\begin{array}{l}4,481 \\
0.01\end{array}$ & $\begin{array}{l}4,481 \\
0.01 \\
\end{array}$ & $\begin{array}{l}4,481 \\
0.01 \\
\end{array}$ & $\begin{array}{l}4,481 \\
0.01 \\
\end{array}$ & $\begin{array}{l}4,481 \\
0.01\end{array}$ \\
\hline
\end{tabular}

To gain insight into the drivers of the positive relationship between policy uncertainty and acquirer BHARs, we examine the link between policy uncertainty and acquirer operating performance. We measure an acquirer's operating performance by its long-term abnormal operating performance (ABN_OP), which is estimated using the matched portfolio-adjusted method (Barber and Lyon (1997)). 
Specifically, we identify a matched portfolio of control firms for each sample firm. The matched portfolio includes firms in the same 2-digit SIC industries that have not been involved in any M\&A deal over the last 3 years, have a pre-merger book value of assets within the range of $70 \%-130 \%$ of the sample firm's book value of assets, and have pre-merger return on assets (ROA; the ratio of the net income to the book value of assets) within $90 \%-110 \%$ of that of the sample firm. We then calculate the ROAs of the sample acquirer and the control firms in the year preceding the M\&A announcement and in each of the 3 years following the M\&A completion. We calculate ABN_OP as the change in portfolio-matched ROAs of the sample firms from the year preceding the M\&A announcement to each of the 3 years after the deal completion (i.e., a difference-in-differences measure).

Table 10 reports the regression results for acquirer operating performance. The coefficients of PU in columns $1-3$ are all positive $(0.021,0.030$, and 0.043 in the first-, second-, and third-year ABN_OP regressions, respectively) and statistically significant. In an alternative specification, we run the long-run operating performance regressions with PU_COMPLETION and report the results in columns 4-6 of Table 10. We find that our results are qualitatively unchanged with this alternative measure of policy uncertainty. Collectively, our evidence indicates that, on average, M\&A deals completed during periods of high policy uncertainty have a positive effect on the acquirers' long-term operating performance. This finding implies that acquirers can obtain greater synergies from M\&A deals pursued during periods of high policy uncertainty, perhaps due to their prudence in screening and selecting relevant acquisition targets.

\section{Robustness Checks}

In this section, we run a battery of robustness checks (to save space, we report some of the results; the remaining results are available from the authors). Policy uncertainty tends to be countercyclical, and both policy uncertainty and M\&As can be jointly correlated with unobservable factors, such as investment opportunities, which raises an endogeneity concern and potentially biases the coefficient estimates of the M\&A probit model. To address this endogeneity concern, we use the IV probit model to reexamine the effect of policy uncertainty on firm acquisitiveness. Following McCarty, Poole, and Rosenthal (1997), Poole and Rosenthal (2000), and Gulen and Ion (2016), we use the partisan polarization measure (POLAR) as an instrument for policy uncertainty. The partisan polarization measure is based on the DW_NOMINATE scores developed by McCarty et al., which track legislators' ideological positions over time. ${ }^{11}$ McCarty (2004) argues that partisan polarization makes it more difficult to build legislation, resulting in policy gridlock and greater variation in policy. In our research context, political polarization should be a valid instrument for policy uncertainty because it is directly

\footnotetext{
${ }^{11}$ The DW_NOMINATE scores represent the ideological positions of legislators. Legislators with similar votes are located near each other, whereas legislators with different preferred outcomes would stay away from each other. The distance between two ideological points (i.e., the difference between two DW_NOMINATE scores) indicates the level of disagreement between two legislators. Readers can refer to McCarty et al. (1997) for more details.
} 
TABLE 10

Policy Uncertainty and Acquirer Long-Term Operating Performance

Table 10 reports the results of the acquirer long-term operating performance (ABN_OP) cross-sectional regressions. The dependent variables are the acquirers' first-, second-, and third-year abnormal operating performance following M\&A deal completion. PU is the natural logarithm of the weighted average of the Baker, Bloom, and Davis (BBD) (2016) policy uncertainty index over the 3-month period at the end of the fiscal year preceding the M\&A announcement. PU_COMPLETION is the natural logarithm of the weighted average of the BBD policy uncertainty index over the 3-month period preceding the deal completion. Other variables are defined in the Appendix. $t$-statistics based on heteroscedasticity-robust standard errors clustered by years are reported in parentheses. ${ }^{*},{ }^{* *}$, and ${ }^{* * *}$ indicate significance at the $10 \%, 5 \%$, and $1 \%$ levels, respectively.

\begin{tabular}{|c|c|c|c|c|c|c|}
\hline \multirow{3}{*}{ Variable } & \multicolumn{6}{|c|}{ Dependent Variable: ABN_OP } \\
\hline & \multirow{2}{*}{$\begin{array}{c}\text { 1st Year } \\
1 \\
\end{array}$} & \multirow{2}{*}{$\begin{array}{l}\text { 2nd Year } \\
\quad 2 \\
\end{array}$} & \multirow{2}{*}{$\begin{array}{c}\text { 3rd Year } \\
3 \\
\end{array}$} & \multirow{2}{*}{$\begin{array}{c}\text { 1st Year } \\
4 \\
\end{array}$} & \multirow{2}{*}{$\begin{array}{l}\text { 2nd Year } \\
\quad 5 \\
\end{array}$} & \multirow{2}{*}{$\begin{array}{c}\text { 3rd Year } \\
6 \\
\end{array}$} \\
\hline & & & & & & \\
\hline PU & $\begin{array}{l}0.021^{*} \\
(1.74)\end{array}$ & $\begin{array}{l}0.030^{\star \star} \\
(2.30)\end{array}$ & $\begin{array}{l}0.043^{* *} \\
(2.06)\end{array}$ & & & \\
\hline PU_COMPLETION & & & & $\begin{array}{l}0.011^{\star} \\
(1.69)\end{array}$ & $\begin{array}{l}0.032^{* *} \\
(2.23)\end{array}$ & $\begin{array}{l}0.044^{*} \\
(1.91)\end{array}$ \\
\hline SIZE & $\begin{array}{l}0.009^{* \star *} \\
(3.44)\end{array}$ & $\begin{array}{l}0.013^{\star \star \star} \\
(2.82)\end{array}$ & $\begin{array}{l}0.010^{\star \star} \\
(2.64)\end{array}$ & $\begin{array}{l}0.010^{\star \star \star} \\
(3.60)\end{array}$ & $\begin{array}{l}0.012^{\star \star} \\
(2.49)\end{array}$ & $\begin{array}{l}0.007^{\star \star} \\
(2.21)\end{array}$ \\
\hline MARKET-TO-BOOK_RATIO & $\begin{array}{l}-0.016^{* * *} \\
(4.95)\end{array}$ & $\begin{array}{l}-0.021^{\star \star \star} \\
(3.17)\end{array}$ & $\begin{array}{l}-0.016^{* * *} \\
(3.08)\end{array}$ & $\begin{array}{l}-0.016^{\star \star \star} \\
(5.00)\end{array}$ & $\begin{array}{l}-0.022^{\star \star *} \\
(3.26)\end{array}$ & $\begin{array}{l}-0.017^{\star \star \star} \\
(3.22)\end{array}$ \\
\hline PAST_12_MONTH_RETURNS & $\begin{array}{l}0.015^{\star *} \\
(2.54)\end{array}$ & $\begin{array}{l}0.002 \\
(0.28)\end{array}$ & $\begin{array}{r}-0.007 \\
(0.86)\end{array}$ & $\begin{array}{l}0.015^{\star \star} \\
(2.50)\end{array}$ & $\begin{array}{l}0.003 \\
(0.42)\end{array}$ & $\begin{array}{c}-0.003 \\
(0.39)\end{array}$ \\
\hline AVERAGE_SALES_GROWTH & $\begin{array}{c}-0.009 \\
(0.73)\end{array}$ & $\begin{array}{c}-0.016 \\
(0.89)\end{array}$ & $\begin{array}{c}0.004 \\
(0.36)\end{array}$ & $\begin{array}{c}-0.009 \\
(0.77)\end{array}$ & $\begin{array}{r}-0.015 \\
(0.82)\end{array}$ & $\begin{array}{l}0.005 \\
(0.49)\end{array}$ \\
\hline BOOK_LEVERAGE & $\begin{array}{r}0.001 \\
(0.03)\end{array}$ & $\begin{array}{l}0.012 \\
(0.39)\end{array}$ & $\begin{array}{c}0.05 \\
(1.49)\end{array}$ & $\begin{array}{r}-0.001 \\
(0.04)\end{array}$ & $\begin{array}{l}0.016 \\
(0.54)\end{array}$ & $\begin{array}{l}0.061 \\
(1.63)\end{array}$ \\
\hline $\begin{array}{l}\text { NONCASH_WORKING_ } \\
\text { CAPITAL }\end{array}$ & $\begin{array}{l}0.056^{* *} \\
(2.35)\end{array}$ & $\begin{array}{l}0.036 \\
(0.87)\end{array}$ & $\begin{array}{r}0.011 \\
(0.38)\end{array}$ & $\begin{array}{l}0.053^{\star \star} \\
(2.25)\end{array}$ & $\begin{array}{r}0.047 \\
(1.14)\end{array}$ & $\begin{array}{l}0.025 \\
(0.89)\end{array}$ \\
\hline FIRM_AGE & $\begin{array}{c}0.01 \\
(1.38)\end{array}$ & $\begin{array}{r}0.007 \\
(0.79)\end{array}$ & $\begin{array}{l}0.008 \\
(1.39)\end{array}$ & $\begin{array}{c}0.01 \\
(1.41)\end{array}$ & $\begin{array}{l}0.005 \\
(0.54)\end{array}$ & $\begin{array}{l}0.006 \\
(1.09)\end{array}$ \\
\hline EXCESS_CASH & $\begin{array}{l}0.001^{\text {***}} \\
(3.23)\end{array}$ & $\begin{array}{l}0.001^{\star \star \star} \\
(3.27)\end{array}$ & $\begin{array}{l}0.001^{* * *} \\
(5.61)\end{array}$ & $\begin{array}{l}0.001^{\star \star \star} \\
(3.24)\end{array}$ & $\begin{array}{l}0.001^{* * \star} \\
(3.77)\end{array}$ & $\begin{array}{l}0.001^{\star \star \star} \\
(6.37)\end{array}$ \\
\hline DEAL_RATIO & $\begin{array}{r}-0.007 \\
(1.05)\end{array}$ & $\begin{array}{c}0.005 \\
(1.07)\end{array}$ & $\begin{array}{c}0.001 \\
(0.04)\end{array}$ & $\begin{array}{r}-0.007 \\
(0.99)\end{array}$ & $\begin{array}{c}0.005 \\
(1.14)\end{array}$ & $\begin{array}{c}0.002 \\
(0.24)\end{array}$ \\
\hline STOCK_DUMMY & $\begin{array}{c}-0.019 \\
(1.47)\end{array}$ & $\begin{array}{l}0.018 \\
(0.94)\end{array}$ & $\begin{array}{c}-0.01 \\
(0.55)\end{array}$ & $\begin{array}{c}-0.02 \\
(1.52)\end{array}$ & $\begin{array}{c}0.025 \\
(1.29)\end{array}$ & $\begin{array}{c}0.001 \\
(0.03)\end{array}$ \\
\hline CASH_DUMMY & $\begin{array}{l}0.006 \\
(0.81)\end{array}$ & $\begin{array}{l}0.027^{\star \star} \\
(2.11)\end{array}$ & $\begin{array}{l}0.025^{*} \\
(2.04)\end{array}$ & $\begin{array}{r}0.007 \\
(0.84)\end{array}$ & $\begin{array}{l}0.025^{*} \\
(2.02)\end{array}$ & $\begin{array}{l}0.021^{\star} \\
(1.78)\end{array}$ \\
\hline HIGH_TECH_DUMMY & $\begin{array}{c}-0.012 \\
(1.55)\end{array}$ & $\begin{array}{l}-0.025^{\star \star \star} \\
(2.87)\end{array}$ & $\begin{array}{c}-0.020^{* *} \\
(2.71)\end{array}$ & $\begin{array}{c}-0.012 \\
(1.53)\end{array}$ & $\begin{array}{l}-0.027^{\star \star \star} \\
(3.03)\end{array}$ & $\begin{array}{l}-0.021^{\star \star} \\
(2.61)\end{array}$ \\
\hline DIVERSIFYING_DUMMY & $\begin{array}{c}-0.013^{*} \\
(1.68)\end{array}$ & $\begin{array}{c}-0.019^{\star} \\
(1.73)\end{array}$ & $\begin{array}{c}0.001 \\
(0.13)\end{array}$ & $\begin{array}{c}-0.013^{\star} \\
(1.70)\end{array}$ & $\begin{array}{r}-0.017 \\
(1.62)\end{array}$ & $\begin{array}{c}0.004 \\
(0.68)\end{array}$ \\
\hline HOSTILE_DUMMY & $\begin{array}{r}0.031 \\
(0.51)\end{array}$ & $\begin{array}{c}0.014 \\
(0.63)\end{array}$ & $\begin{array}{c}0.002 \\
(0.16)\end{array}$ & $\begin{array}{c}0.031 \\
(0.51)\end{array}$ & $\begin{array}{c}0.012 \\
(0.45)\end{array}$ & $\begin{array}{r}0.007 \\
(0.40)\end{array}$ \\
\hline PUBLIC_TARGET_DUMMY & $\begin{array}{c}0.013 \\
(1.18)\end{array}$ & $\begin{array}{c}0.014 \\
(1.35)\end{array}$ & $\begin{array}{c}-0.013 \\
(0.45)\end{array}$ & $\begin{array}{l}0.013 \\
(1.18)\end{array}$ & $\begin{array}{c}0.014 \\
(1.37)\end{array}$ & $\begin{array}{c}-0.012 \\
(0.43)\end{array}$ \\
\hline CHALLENGE_DUMMY & $\begin{array}{c}-0.025 \\
(1.24)\end{array}$ & $\begin{array}{c}-0.023 \\
(1.46)\end{array}$ & $\begin{array}{c}-0.004 \\
(0.14)\end{array}$ & $\begin{array}{c}-0.025 \\
(1.24)\end{array}$ & $\begin{array}{c}-0.024 \\
(1.59)\end{array}$ & $\begin{array}{r}-0.001 \\
(0.03)\end{array}$ \\
\hline $\begin{array}{l}\text { TARGET_INDUSTRY_M\&A_ } \\
\text { INTENSITY }\end{array}$ & $\begin{array}{c}-0.018 \\
(0.39)\end{array}$ & $\begin{array}{l}-0.025^{\star \star} \\
(2.41)\end{array}$ & $\begin{array}{r}-0.001 \\
(0.04)\end{array}$ & $\begin{array}{l}(0.02) \\
(0.40)\end{array}$ & $\begin{array}{l}-0.027^{* *} \\
(2.41)\end{array}$ & $\begin{array}{c}-0.002 \\
(0.21)\end{array}$ \\
\hline Intercept & $\begin{array}{l}-0.190^{* * *} \\
(3.29)\end{array}$ & 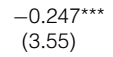 & $\begin{array}{l}-0.301^{* *} \\
(2.49)\end{array}$ & $\begin{array}{l}-0.147^{\star \star \star} \\
(2.60)\end{array}$ & $\begin{array}{l}-0.243^{\star \star \star} \\
(3.30)\end{array}$ & $\begin{array}{l}-0.284^{\star \star} \\
(2.22)\end{array}$ \\
\hline $\begin{array}{l}\text { No. of obs. } \\
\text { Adj. } R^{2}\end{array}$ & $\begin{array}{l}1,452 \\
0.06\end{array}$ & $\begin{array}{l}1,311 \\
0.07\end{array}$ & $\begin{array}{l}1,152 \\
0.08\end{array}$ & $\begin{array}{l}1,452 \\
0.06\end{array}$ & $\begin{array}{l}1,311 \\
0.07\end{array}$ & $\begin{array}{l}1,152 \\
0.07\end{array}$ \\
\hline
\end{tabular}

related to policy uncertainty but unlikely to have a direct impact on a firm's acquisitiveness except indirectly through policy uncertainty.

The first-stage results of the IV probit model estimation reported in column 1 of Table 11 show that the coefficient on the instrument is positive $(0.435)$ and significant at the $1 \%$ level, confirming its relevance. The Kleibergen-Paap 
TABLE 11

Policy Uncertainty and Firm Acquisitiveness:

IV Probit Model and 2-Step Error-in-Measurement Correction Model

Table 11 reports the results of the 2-stage IV probit regression in columns 1 and 2 and the results of the second step of the 2-step error-in-measurement correction probit model in column 3. The dependent variable is M\&A DUMMY, which takes a value of 1 if a firm makes at least one M\&A announcement in a given year, and 0 otherwise. RPU is the residuals from the regression of the U.S. news-based uncertainty measure on the Canadian news-based uncertainty measure and the country-level average TOBINS_Q, cash flows, 3-year average sales growth, and investment irreversibility measures. POLAR is a measure of political polarization of the U.S. Senate used as the instrument for policy uncertainty. Other variables are defined in the Appendix. Z-statistics based on heteroscedasticity-robust standard errors clustered by years are reported in parentheses. *, ${ }^{* *}$, and ${ }^{* * *}$ indicate significance at the $10 \%, 5 \%$, and $1 \%$ levels, respectively.

\begin{tabular}{|c|c|c|c|}
\hline \multirow{4}{*}{ Variable } & \multicolumn{3}{|c|}{ Dependent Variable: M\&A_DUMMY } \\
\hline & \multicolumn{2}{|c|}{ IV Probit Model } & \multirow{2}{*}{$\begin{array}{c}\text { 2-Step Error-in- } \\
\text { Measurement } \\
\text { Correction Probi } \\
\text { Model }\end{array}$} \\
\hline & First Stage & Second Stage & \\
\hline & 1 & 2 & 3 \\
\hline POLAR & $\begin{array}{l}0.435^{\star \star \star} \\
(40.11)\end{array}$ & & \\
\hline INSTRUMENTED_PU & & $\begin{array}{l}-1.831^{* \star \star} \\
(19.17)\end{array}$ & \\
\hline RPU & & & $\begin{array}{l}-0.002^{\star \star *} \\
(6.09)\end{array}$ \\
\hline SIZE & $\begin{array}{r}-0.001 \\
(1.15)\end{array}$ & $\begin{array}{l}0.157^{\star \star \star} \\
(51.37)^{-}\end{array}$ & $\begin{array}{l}0.167^{\star \star \star} \\
(64.80)\end{array}$ \\
\hline MARKET-TO-BOOK_RATIO & $\begin{array}{l}-0.021^{\star \star \star} \\
(28.18)\end{array}$ & $\begin{array}{c}0.006 \\
(1.40)\end{array}$ & $\begin{array}{l}0.045^{\star \star \star} \\
(11.93)\end{array}$ \\
\hline PAST_12_MONTH_RETURNS & $\begin{array}{l}-0.016^{\star \star \star} \\
(11.88)\end{array}$ & $\begin{array}{l}0.062^{* \star \star} \\
(8.37)\end{array}$ & $\begin{array}{l}0.113^{\star \star \star} \\
(15.25)\end{array}$ \\
\hline AVERAGE_SALES_GROWTH & $\begin{array}{l}-0.008^{\star \star \star} \\
(3.81)\end{array}$ & $\begin{array}{l}0.026^{* *} \\
(2.41)\end{array}$ & $\begin{array}{l}0.051^{\star \star \star} \\
(4.43)\end{array}$ \\
\hline BOOK_LEVERAGE & $\begin{array}{c}-0.008 \\
(1.56)\end{array}$ & $\begin{array}{l}-0.432^{\star * *} \\
(16.94)\end{array}$ & $\begin{array}{l}-0.409^{\star \star \star} \\
(15.16)\end{array}$ \\
\hline NONCASH_WORKING_CAPITAL & $\begin{array}{l}-0.054^{\star \star \star} \\
(9.31)\end{array}$ & $\begin{array}{l}0.054^{*} \\
(1.76)\end{array}$ & $\begin{array}{l}0.259^{\star \star \star} \\
(8.24)\end{array}$ \\
\hline FIRM_AGE & $\begin{array}{l}0.017^{\star \star \star} \\
(10.57)\end{array}$ & $\begin{array}{l}0.077^{\star \star \star} \\
(9.66)\end{array}$ & $\begin{array}{l}0.042^{\star \star \star} \\
(5.02)\end{array}$ \\
\hline Intercept & $\begin{array}{l}4.345^{\star \star \star} \\
(502.05)\end{array}$ & $\begin{array}{l}6.999^{\star * *} \\
(15.02)\end{array}$ & $\begin{array}{l}-2.055^{\star \star \star} \\
(32.70)\end{array}$ \\
\hline Industry fixed effects & Yes & Yes & Yes \\
\hline No. of obs. & 88,768 & 88,768 & 88,768 \\
\hline $\begin{array}{l}\text { Underidentification test } \\
\quad \text { Kleibergen-Paap Wald F-statistic }\end{array}$ & $854.75^{\star \star *}$ & & \\
\hline $\begin{array}{l}\text { Weak identification test } \\
\text { Cragg-Donald Wald F-statistic }\end{array}$ & $1,571.50^{* * *}$ & & \\
\hline $\begin{array}{l}\text { Weak instrument robust inference } \\
\text { Anderson-Rubin Wald test }\end{array}$ & $292.10^{* * *}$ & & \\
\hline
\end{tabular}

underidentification test statistic and the Cragg-Donald weak identification test statistic further indicate that our selected instrument is relevant. ${ }^{12}$ The results of the outcome regression reported in column 2 of Table 11 show that the coefficient of INSTRUMENTED_PU is negative $(-1.831)$ and highly significant, indicating that our findings are robust to endogeneity correction. In an unreported analysis, we further control for investment opportunities proxied by real GDP growth rates, expected GDP growth, the Conference Board's Leading Economic Index, and the

\footnotetext{
${ }^{12}$ Because the model is just identified, we cannot perform the overidentification test. However, we find that the coefficient of correlation between political polarization and the M\&A dummy is 0.03 , which implies a weak relationship between the two variables.
} 
Michigan Consumer Confidence Index in our M\&A probit model, but our findings persist.

The BBD (2016) index may capture the effects of general economic uncertainty that potentially confound our finding of a negative relationship between policy uncertainty and firm acquisitiveness. We address this concern by controlling for several proxies for economic uncertainty suggested by Bloom (2009) in our M\&A probit model. First, using the GDP forecast data from the Philadelphia Federal Reserve's Livingston survey, we calculate the coefficient of variation of GDP forecast as a proxy for expected economic growth uncertainty. Second, we estimate the annual cross-sectional standard deviation of firm profit growth as a proxy for future profitability variation, where firm profit growth is defined as the ratio of the change in net income to average sales. Third, we control for the uncertainty of the equity markets proxied by the monthly standard deviation of stock returns and the CBOE's VXO index of implied volatility. Finally, we control for an alternative measure of aggregate macroeconomic uncertainty suggested by Jurado, Ludvigson, and $\mathrm{Ng}$ (2015). We augment our baseline M\&A probit model with these five general economic uncertainty proxies, but our finding is qualitatively unchanged. In addition, to alleviate concern about collinearity between policy and economic uncertainty, we run a 2-step probit model to isolate the effects of policy uncertainty from those of economic uncertainty. Specifically, in the first step, we regress the BBD index on the five economic uncertainty variables and obtain the residuals. We then rerun the M\&A probit model using these residuals as a proxy for policy uncertainty but find qualitatively similar results. Finally, we run a "kitchen sink" M\&A probit regression that includes all five general economic uncertainty proxies and the four investment opportunity proxies discussed earlier, but our finding is qualitatively similar. ${ }^{13}$

Because policy uncertainty tends to be countercyclical, in the next analysis, we identify countercyclical and procyclical industries based on the asset liquidation values proxied by firms' sale cyclicality (Shleifer and Vishny (1992), Sharpe (1994), and Almeida and Campello (2007)). We estimate the coefficient of the correlation between a firm's sales and the annual gross national product (GNP) over our sample period and calculate industry-level correlation coefficients as the average of the correlation coefficients of the firms in the same 2-digit SIC industry. We sort industries into the procyclical (countercyclical) subgroup if their correlation coefficients are above (below) the sample median. Then we rerun the M\&A probit models separately for firms in each subgroup. If policy uncertainty captures the effects that are different from those captured by economic uncertainty, we expect the negative relationship between policy uncertainty and M\&A acquisitiveness to hold for firms in the countercyclical industries. Consistent with our expectation, the estimation results indicate that policy uncertainty has a negative effect on the M\&A acquisitiveness for firms in both industry subgroups and such effect appears to be even stronger for firms in the countercyclical industries. ${ }^{14}$

\footnotetext{
${ }^{13}$ We also include the five general economic uncertainty proxies and the four investment opportunity proxies in the acquirer CAR regressions, but our finding is virtually unchanged.

${ }^{14} \mathrm{We}$ thank the referee for the suggestion to perform this analysis.
} 
To further distinguish the effects of policy uncertainty from those of economic uncertainty, we rerun our M\&A probit model separately for the growth and recession periods, which are defined based on National Bureau of Economic Research (NBER) business-cycle data. If policy uncertainty simply picks up the effects of economic uncertainty, we expect the negative effect of policy uncertainty on M\&A acquisitiveness to be significant (insignificant) during the recession (growth) periods. However, our unreported results indicate that the negative relation between policy uncertainty and M\&A acquisitiveness is significant in both periods, implying that our results are not confounded by the effects of economic uncertainty.

Another potential issue with using the BBD (2016) index as a proxy for policy uncertainty is that it can capture the effects of other, nonpolicy-related factors, such as currency uncertainty or labor market variations, which raises an error-inmeasurement concern that could bias the estimation results of the M\&A probit model. We address the error-in-measurement concern by using the 2-step regression approach. In the first step, we regress the measure of the news-based component of the U.S. BBD policy uncertainty index on the Canadian news-based uncertainty measure and the country-level average Tobin's $Q$, cash flows, average sales growth, and investment irreversibility measures. ${ }^{15}$ We obtain the regression residuals (labeled RPU), which are the difference between the actual and the predicted U.S. news-based uncertainty measure. Given the close relationship between the U.S. and Canadian economies, the residuals from a regression of the U.S. news-based policy uncertainty measure on the Canadian one should be free from potential confounding effects of the macroeconomic forces common to both countries. We then rerun the M\&A probit regressions with RPU in place of PU and report the estimation results in column 4 of Table 11 . The coefficient of RPU is negative $(-0.002)$ and statistically significant. This evidence further corroborates our finding of a negative relationship between policy uncertainty and firm acquisitiveness.

Because the effects of policy uncertainty on acquisitions can go beyond the firm level, we further investigate the relationships between policy uncertainty and the number and value of M\&A deals at the industry level. We run the industrylevel regressions with either the natural logarithm of the number of M\&A deals or the natural logarithm of the aggregate M\&A deal value for each industry in a given year as the dependent variable. The regressions control for industry value-weighted average market-to-book ratio, GDP growth, yield spread, and CRSP value-weighted index returns. The estimation results reported in Table 12 indicate that PU is negative $(-0.682$ and -0.747 in the number and value of deal regressions, respectively) and significant at the $1 \%$ level, suggesting that the negative effects of policy uncertainty on M\&A activities extend beyond the firm level.

The BBD (2016) index is constructed based on the three components of news-based uncertainty, tax-related uncertainty, and fiscal and monetary policy uncertainty, but their effects on firm acquisitiveness may vary. The news-based

\footnotetext{
${ }^{15}$ Note that the Canadian BBD (2016) policy uncertainty index includes only news-based uncertainty.
} 


\begin{tabular}{|c|c|c|}
\hline & $\begin{array}{c}\text { No. of } \\
\text { M\&A Deals }\end{array}$ & $\begin{array}{c}\text { Aggregate M\&A } \\
\text { Deal Values }\end{array}$ \\
\hline Variable & 1 & 2 \\
\hline PU & $\begin{array}{l}-0.682^{\star \star \star} \\
(3.72)\end{array}$ & $\begin{array}{l}-0.747^{\star \star \star} \\
(3.31)\end{array}$ \\
\hline MARKET-TO-BOOK_RATIO & $\begin{array}{l}0.105^{\star \star \star} \\
(3.97)\end{array}$ & $\begin{array}{l}0.120^{* * *} \\
(4.30)\end{array}$ \\
\hline GDP_GROWTH & $\begin{array}{c}-0.008 \\
(0.29)\end{array}$ & $\begin{array}{c}0.043 \\
(1.26)\end{array}$ \\
\hline YIELD_SPREAD & $\begin{array}{l}0.183^{*} \\
(1.77)\end{array}$ & $\begin{array}{l}0.874^{\star * \star} \\
(6.30)\end{array}$ \\
\hline MARKET_RETURNS & $\begin{array}{l}2.028 \\
(0.87)\end{array}$ & $\begin{array}{l}13.361^{\text {** }} \\
(3.67)\end{array}$ \\
\hline Intercept & $\begin{array}{l}6.607^{\star \star \star} \\
(7.56)\end{array}$ & $\begin{array}{l}9.663^{\text {** }} \\
(9.16)\end{array}$ \\
\hline $\begin{array}{l}\text { No. of obs. } \\
\text { Adj. } R^{2}\end{array}$ & $\begin{array}{l}1,969 \\
0.05\end{array}$ & $\begin{array}{l}1,969 \\
0.04\end{array}$ \\
\hline
\end{tabular}

component is important because this component captures the uncertainty associated with all policy decisions, including those related to government spending, inflation, and tax. The fiscal and monetary uncertainty component can have a negative effect on firm acquisitiveness because it can affect the demand for firm output, capital supply, or the costs of capital, among others. However, by construction, the effect of the tax-related component on M\&As is unclear or might even be positive. The reason is that the expiration of a tax code may effectively lead to higher business or personal tax rates, motivating firms to accelerate M\&A deals before its expiration. For instance, the Bush tax cuts that were set to expire at the end of 2010 would effectively increase the federal capital gain tax rate from $15 \%$ to as high as $23.8 \%$ (including a surtax to support Obamacare). Given the tax increase, if a $100 \%$ equity-financed firm plans to sell itself for $\$ 100$ million, the total capital gain tax increase incurred by its shareholders would be $\$ 880,000$. To put it a different way, in order to achieve the same net proceeds after the expiration of the Bush tax cuts, the firm would have to sell for $\$ 111.15$ million. Therefore, after the expiration of the Bush tax cuts, acquirers would have to pay higher prices to offset the increase in tax payment by the target shareholders, and/or the target shareholders would have to accept lower net proceeds. Another example is the provisions of the Protecting Americans from Tax Hikes (PATH) Act of 2015, which allow businesses with large investments to expense immediately $50 \%$ of some investment costs, leading to lower taxable income. Because these provisions are due to expire by the end of 2019 and their extension is uncertain, firms may have an incentive to accelerate asset acquisitions before these provisions expire. 
To investigate the effect of each policy uncertainty component on firm acquisitiveness while avoiding a possible collinearity problem, we rerun the M\&A probit model with each component of the BBD (2016) index separately and report the results in Table A1 in the Internet Appendix (available at www.jfqa.org). The results indicate that the news-based uncertainty and fiscal and monetary policy uncertainty have negative effects on firm acquisitiveness, whereas the uncertainty related to tax-code expiration has an insignificant effect on firm acquisitiveness. We further examine the effects of the three components of the BBD index on acquirer and target CARs separately and report the results in Table A2 in the Internet Appendix. The results indicate that all three policy uncertainty components have positive effects on acquirer CARs but negative effects on target CARs.

Previous research documents that political uncertainty is positively related to national elections and that this relationship has an important bearing on corporate decisions and asset prices. Bialkowski, Gottschalk, and Wisniewski (2008) and Boutchkova, Doshi, Durnev, and Molchanov (2012) report that firms operating in politically related industries tend to experience higher stock return volatility during presidential election periods. Using a sample that includes 248 national elections in 48 countries over the period 1980-2005, Julio and Yook (2012) document a negative effect of presidential elections on investments. To the extent that presidential elections introduce other types of uncertainty that are different from the policy-related one, our M\&A probit estimation can be prone to the omittedvariable problem, potentially leading to biased coefficient estimates. Therefore, we control for the effect of presidential elections on firm acquisitiveness by augmenting the M\&A probit model with an election indicator variable that takes a value of 1 for a presidential election year during the sample period, and 0 otherwise. Our unreported estimation results indicate that the coefficient of PU remains negative $(-0.212)$ and significant at the $5 \%$ level, whereas the coefficient of the presidential election indicator is negative $(-0.023)$ but statistically insignificant. We also rerun the CARs cross-sectional regression that additionally controls for the presidential election effects and find that the coefficient of PU remains positive $(0.015)$ and significant at the $1 \%$ level, whereas the coefficient of the presidential election indicator is negative $(-0.001)$ but statistically insignificant. Taken together, the evidence indicates that our findings are robust to controlling for presidential elections.

In another robustness check, we estimate the M\&A probit model separately for financially constrained and unconstrained acquirer subgroups. We use the S\&P long-term credit ratings to sort acquiring firms into financially unconstrained (with S\&P long-term credit ratings) and constrained (without S\&P long-term credit ratings) subgroups. The results reported in columns 1 and 2 of Table A3 in the Internet Appendix indicate that the negative effect of PU on M\&A acquisitiveness is statistically significant for financially constrained acquirers. In contrast, the results indicate that financially unconstrained acquirers are more likely to pursue M\&A deals during periods of high policy uncertainty. This evidence is consistent with the notion that financially constrained firms are more prudent with M\&As during periods of high policy uncertainty, whereas financially unconstrained firms may perceive policy uncertainty as an opportunity to pursue acquisitions, perhaps for a bargain. 
We note that policy uncertainty exacerbates financial constraints, which can substitute for corporate governance in mitigating managerial discretion and overinvestment. To the extent that policy uncertainty can act as an external disciplinary force, we expect its positive effect on M\&A performance to be stronger for acquirers with poor corporate governance. To explore this possibility, similar to previous research (e.g., Masulis et al. (2007)), we use the index of Gompers, Ishii, and Metrick (GIM) (2003), which measures the number of antitakeover provisions that a firm adopts, and blockholder ownership as proxies for external and internal corporate governance, respectively. GIM index values range from 0 to 24. A large (small) value for the GIM index is considered poor (good) corporate governance. A larger (smaller) blockholder ownership is considered good (poor) corporate governance. We include both the stand-alone measures of corporate governance and their interactions with policy uncertainty in the acquirer CAR model and rerun the cross-sectional regressions; however, the interaction effects are statistically insignificant, whereas the effect of policy uncertainty is virtually unchanged. In an alternative specification, we use the index of Bebchuk, Cohen, and Ferrell (BCF) (2009) in place of the GIM index. The BCF index is built based on the six most important antitakeover provisions, which are staggered boards, supermajority requirements for mergers, supermajority requirements for charter amendments, limits to shareholder bylaw amendments, poison pills, and golden parachutes, to proxy for managerial entrenchment. However, our findings are qualitatively similar. ${ }^{16}$

We also reestimate the CAR cross-sectional regressions for financially constrained and unconstrained acquirer subgroups sorted on S\&P long-term credit ratings. The results reported in Table A4 in the Internet Appendix indicate that PU has a positive effect on acquirer shareholder value for both subgroups, and such effect is more pronounced for financially constrained acquirers. ${ }^{17}$

Because all accounting data are available on an annual basis, we perform analyses using annual data. For a robustness check, we rerun the M\&A probit model using quarterly $\mathrm{M} \& \mathrm{~A}$ and accounting data and employing the regression specifications similar to equation (1). M\&A_DUMMY is an indicator that equals 1 if a firm makes at least one acquisition announcement in a given quarter, and 0 otherwise. A firm's accounting variables are measured at the end of the quarter preceding the M\&A deal announcement. Our unreported estimation results indicate that the coefficient of policy uncertainty is negative $(-0.241)$ and significant at the $1 \%$ level, implying that the negative relationship between policy uncertainty and $M \& A$ acquisitiveness is robust to quarterly data.

Finally, because policy uncertainty adversely affects firm acquisitiveness, we are interested in tracking the evolution of the effect of policy uncertainty on firm acquisitiveness by running 24 separate M\&A probit regressions, corresponding to lags 1-24 of policy uncertainty, and plot the coefficients of policy uncertainty in Figure $1 \mathrm{~A}$ in the Internet Appendix. The graph indicates that the negative effect

\footnotetext{
${ }^{16}$ We thank the referee for suggesting policy uncertainty as an external disciplining force.

${ }^{17}$ In an unreported analysis, we estimate the targetiveness probit models separately for financially constrained and unconstrained subgroups, sorted on the S\&P long-term credit ratings, but the results are insignificant. We also investigate the relationships between PU and firm acquisitiveness and targetiveness conditional on firms' dependence on government spending, but the results are inconclusive.
} 
of policy uncertainty on firm acquisitiveness weakens over time but persists for up to 4 years, which is approximately 1 year longer than its effect on capital expenditures as reported by Gulen and Ion (2016), perhaps due to the large capital commitment to and the riskiness of M\&A deals.

\section{Conclusions}

Policy uncertainty is an important factor that firms take into account when they make investment decisions. This research investigates the relationship between policy uncertainty and M\&As, an important form of corporate investments. Using the BBD (2016) index as a proxy for policy uncertainty, we find robust evidence of a negative relationship between policy uncertainty and firm acquisitiveness. Even if firms decide to pursue M\&A deals in the first place, it takes them longer to complete the deals during periods of high policy uncertainty. Acquirers are also more prudent with their payment for M\&A targets, as evidenced by their preference for stock payment and lower bid premiums. However, M\&A deals undertaken during periods of high policy uncertainty appear to improve acquirer operating performance and create greater shareholder value, findings that are attributable to acquirer prudence as well as the value transfer from financially constrained targets to acquirers. Finally, we find that policy uncertainty has negative effects on both the number and the aggregate value of M\&A deals at the industry level, indicating the far-reaching consequences of policy uncertainty.

\section{Appendix. Variable Definitions}

AVERAGE_SALES_GROWTH: Average annual sales growth over the last 3 years. Source: Compustat.

BOOK_LEVERAGE: The ratio of the book value of short-term and long-term debt to the book value of assets. Source: Compustat.

CAR: The cumulative abnormal stock return over the window $(-1,+1)$ centered on the M\&A announcement day. Source: CRSP and SDC Platinum.

CASH_DUMMY: An indicator that equals 1 if an M\&A deal is fully funded by cash, and 0 otherwise. Source: SDC Platinum.

CHALLENGE_DUMMY: An indicator that equals 1 if the acquirer's offer is challenged by a competing offer, and 0 otherwise. Source: SDC Platinum.

DEAL_RATIO: The ratio of M\&A deal value to an acquirer's market value of equity measured 4 weeks before a deal announcement. Source: SDC Platinum.

DIVERSIFYING_DUMMY: An indicator that equals 1 if the acquirer and target belong to different 2-digit SIC code industries, and 0 otherwise. Source: Compustat.

EXCESS_CASH: The difference between expected cash holding and realized cash holding. Source: Compustat.

FIRM_AGE: Number of years that a firm appears in Compustat. Source: Compustat.

HIGH_TECH_DUMMY: An indicator that equals 1 if an acquirer's 4-digit SIC code is equal to $3571,3572,3575,3577,3578,3661,3663,3669,3671,3672,3674,3675$, $3677,3678,3679,3812,3823,3825,3826,3827,3829,3841,3845,4812,4813$, 4899, 7371-7375, 7378, or 7379, and 0 otherwise. Source: Compustat.

HOSTILE_DUMMY: An indicator that equals 1 if the M\&A deal is a hostile takeover, and 0 otherwise. Source: SDC Platinum. 
IMR: The inverse Mill's ratio, calculated using the M\&A probit estimates. Source: Compustat and SDC Platinum.

M\&A_DUMMY: An indicator that equals 1 if a firm makes an M\&A announcement in a given year, and 0 otherwise. Source: SDC Platinum.

MARKET-TO-BOOK_RATIO: The ratio of the market value of assets to the book value of assets. Source: Compustat.

NONCASH_WORKING_CAPITAL: The ratio of (working capital - cash) to the book value of assets. Source: Compustat.

PAST_12_MONTH_RETURNS: The buy-and-hold 12-month stock return of the year preceding an M\&A announcement. Source: CRSP.

POLICY_UNCERTAINTY: The natural logarithm of the weighted average of the BBD (2016) index over the 3-month period at the end of a year.

PUBLIC_TARGET_DUMMY: An indicator that equals 1 for a publicly listed target, and 0 otherwise. Source: SDC Platinum.

SIZE: The natural logarithm of the book value of assets. Source: Compustat.

STOCK_DUMMY: An indicator that equals 1 if the payment is fully in stock, and 0 otherwise. Source: SDC Platinum.

TARGET_INDUSTRY_M\&A_INTENSITY: The ratio of target book value of assets to the sum of total assets of all firms in the same 2-digit SIC code industry and year. Source: Compustat and SDC Platinum.

TOBINS_Q: (Book value of assets - book value of equity + market value of equity deferred taxes)/book value of assets. Source: Compustat.

\section{References}

Abel, A. B. "Optimal Investment under Uncertainty." American Economic Review, 73 (1983), $228-233$.

Abel, A. B., and J. C. Eberly. "A Unified Model of Investment under Uncertainty." American Economic Review, 5 (1994), 1369-1384.

Almeida, H., and M. Campello. "Financial Constraints, Asset Tangibility, and Corporate Investment." Review of Financial Studies, 20 (2007), 1429-1460.

Baker, S.; N. Bloom; and S. Davis. "Measuring Economic Policy Uncertainty." Quarterly Journal of Economics, 131 (2016), 1593-1636.

Barber, B., and J. Lyon. "Detecting Abnormal Operating Performance: The Empirical Power and Specification of Test Statistics." Journal of Financial Economics, 41 (1996), 359-399.

Barber, B., and J. Lyon. "Detecting Long-Run Abnormal Stock Returns: The Empirical Power and Specification of Test Statistics." Journal of Financial Economics, 43 (1997), 341-372.

Bebchuk, L.; A. Cohen; and A. Ferrell. "What Matters in Corporate Governance? Review of Financial Studies, 22 (2009), 783-827.

Bernanke, B. S. "Irreversibility, Uncertainty, and Cyclical Investment." Quarterly Journal of Economics, 98 (1983), 85-106.

Bhagwat, V.; R. Dam; and J. Harford. "The Real Effect of Uncertainty on Merger Activity.” Review of Financial Studies, 29 (2016), 3000-3034.

Bialkowski, J.; K. Gottschalk; and T. P. Wisniewski. "Stock Market Volatility around National Elections." Journal of Banking and Finance, 32 (2008), 1941-1953.

Bloom, N. "The Impact of Uncertainty Shocks." Econometrica, 77 (2009), 623-685.

Bloom, N.; S. Bond; and J. Reenen. "Uncertainty and Investment Dynamics." Review of Economic Studies, 74 (2007), 391-415.

Boutchkova, M.; H. Doshi; A. Durnev; and A. Molchanov. "Precarious Politics and Return Volatility." Review of Financial Studies, 25 (2012), 1111-1154.

Brogaard, J., and A. Detzel. "The Asset-Pricing Implications of Government Economic Policy Uncertainty." Management Science, 61 (2015), 3-18.

Caballero, R. "On the Sign of the Investment-Uncertainty Relationship." American Economic Review, 81 (1991), 279-288. 
Dimopoulos, T., and S. Sacchetto. "Preemptive Bidding, Target Resistance, and Takeover Premiums." Journal of Financial Economics, 114 (2014), 444-470.

Dixit, A., and R. Pindyck. Investment under Uncertainty. Princeton, NJ: Princeton University Press (1994).

Furfine, C. H., and R. Rosen. "Mergers Increase Default Risk.” Journal of Corporate Finance, 17 (2011), 832-849.

Gilchrist, S.; J. Sim; and E. Zakrajšek. "Uncertainty, Financial Frictions, and Investment Dynamics." Working Paper, National Bureau of Economic Research (2014).

Gompers, P. A.; J. L. Ishii; and A. Metrick. "Corporate Governance and Equity Prices." Quarterly Journal of Economics, 118 (2003), 107-155.

Greenwald, B., and J. Stiglitz. "Macroeconomic Models with Equity and Credit Rationing." In Asymmetric Information, Corporate Finance, and Investment, R. G. Hubbard, ed. Chicago, IL: University of Chicago Press (1990), 15-42.

Gulen, H., and M. Ion. "Policy Uncertainty and Corporate Investment." Review of Financial Studies, 29 (2016), 523-564.

Harford, J. “Corporate Cash Reserves and Acquisitions.” Journal of Finance, 54 (1999), 1969-1997.

Hartman, R. "The Effects of Price and Cost Uncertainty on Investment." Journal of Economic Theory, 5 (1972), 258-266.

Heckman, J. "The Common Structure of Statistical Models of Truncation, Sample Selection and Limited Dependent Variables and a Simple Estimator for Such Models." Annals of Economic and Social Measurement, 5 (1976), 475-492.

Heckman, J. "Sample Selection Bias as a Specification Error.” Econometrica, 47 (1979), 153-161.

International Monetary Fund. World Economic Outlook: Coping with High Debt and Sluggish Growth. Washington, DC: IMF Press (2012).

Jens, C. "Political Uncertainty and Investment: Causal Evidence from U.S. Gubernatorial Elections." Journal of Financial Economics, (2017), forthcoming.

Julio, B., and Y. Yook. "Political Uncertainty and Corporate Investment Cycles." Journal of Finance, 67 (2012), 45-83.

Jurado, K.; S. Ludvigson; and S. Ng. "Measuring Uncertainty." American Economic Review, 105 (2015), 1177-1216.

Lyon, J.; B. Barber; and C. Tsai. "Improved Methods for Tests of Long-Run Abnormal Stock Returns." Journal of Finance, 54 (1999), 165-201.

Masulis, R.; C. Wang; and F. Xie. "Corporate Governance and Acquirer Returns." Journal of Finance, 62 (2007), 1851-1889.

McCarty, N. "The Policy Consequences of Partisan Polarization in the United States." Paper Presentation, Seminar of Institutions and Positive Political Theory, University of California, Berkeley (2004).

McCarty, N.; K. Poole; and H. Rosenthal. Income Redistribution and the Realignment of American Politics. Washington, DC: SEI Press (1997).

McDonald, R., and D. Siegel. "The Value of Waiting to Invest." Quarterly Journal of Economics, 101 (1986), 707-728.

Moeller, S.; F. Schlingemann; and R. Stulz. "Wealth Destruction on a Massive Scale? A Study of Acquiring-Firm Returns in the Recent Merger Wave.” Journal of Finance, 60 (2005), 757-782.

Officer, M. "Termination Fees in Mergers and Acquisitions." Journal of Financial Economics, 69 (2003), 431-467.

Panousi, V., and D. Papanikolaou. "Investment, Idiosyncratic Risk, and Ownership." Journal of Finance, 67 (2012), 1113-1148.

Pástor, L., and P. Veronesi. "Political Uncertainty and Risk Premia." Journal of Financial Economics, 110 (2013), 520-545.

Phan, H. V. "Inside Debt and Mergers and Acquisitions." Journal of Financial and Quantitative Analysis, 49 (2014), 1365-1401.

Poole, K., and H. Rosenthal. Congress: A Political-Economic History of Roll Call Voting. New York, NY: Oxford University Press (2000).

Rodrik, D. "Policy Uncertainty and Private Investment in Developing Countries." Journal of Development Economics, 36 (1991), 229-242.

Sharpe, S. A. "Financial Market Imperfections, Firm Leverage, and the Cyclicality of Employment." American Economic Review, 84 (1994), 1060-1074.

Shleifer, A., and R. W. Vishny. "Liquidation Values and Debt Capacity: A Market Equilibrium Approach." Journal of Finance, 47 (1992), 1343-1366.

Stock, J., and M. Watson. "Disentangling the Channels of the 2007-2009 Recession." National Bureau of Economic Research Working Paper 18094 (2012). 